\title{
Future of Heritage - A Condition for Space Integrity
}

\author{
Lemja Chabbouh Akšamija \\ University in Sarajevo, Faculty of Architecture, Sarajevo, \\ Bosnia and Herzegovina
}

\section{Introduction}

"My ideal, however is not to erase national characteristics in the manner leading towards intellectually uniform humanity. To the contrary, long live the variety of all forms and colors on our dear planet Earth. Beautiful is the existence of many races and peoples, multitude of languages, different mentalities and worldviews. If I feel the hostility and irreconcilable intolerance towards wars, conquering and annexations, it is caused by many reasons but mostly because of the fact that many organic, highly individual and sumptuous achievements of human civilization had been victim of those dark forces. I'm the opponent of "grands simplificateurs" and a fan of quality, original skill and uniqueness". Herman Hesse, a part of his address while being awarded the Nobel Prize for Literature in $1946 .{ }^{1}$

Globalization, traditional values, rural architectural heritage, active protection of rural architectural heritage, integral active space protection, cultural landscape, cultural tourism, typology of rural architecture, methodology for identification and preservation of architectural heritage, identification and preservation of authenticity of rural architectural heritage, cultural landscape, ethno villages, methodology of the protection of integral rural spaces.

Researches, which tackle or deeply intrude into tradition and the traditional within architectural heritage, only under superficial assessment, may create conflict with globalization in the widest sense. The changes of the general picture of the world happening on the architectural plan, which will certainly stop to manifest in such intensity in the times to come, are, on one side, the result of "exhibitionism" to which the investors are ready, and the result of the economic momentum that is actually passing by which marked its existence with unique facilities of universal characteristics, with no stylish and traditional characteristics, with extraordinary technological performances.

\footnotetext{
1 "Doch ist mein Ideal keineswegs eine Verwischung der nationalen Charaktere zugunsten einer geistig uniformierten Gesamtmenschheit. $\mathrm{O}$ nein, es lebe die Mannigfaltigkeit, die Differenzierung und Stufung auf unserer lieben Erde! Herrlich ist es, dass es viele Rassen und Völker gibt, viele Sprachen, viele Spielarten der Mentalität und Weltanschaungen. Wenn ich ein Hasser und unversöhnlicher Gegner der Kriege, der Eroberungen und Annexionen bin, so bin ich es unter andrem auch aus dem Grunde, weil diesen finstern Mächten so viel an geschichtlich Gewordenem, hoch Individualisiertem, reich Differenziertem an menschlicher Kultur zum Opfer fällt. Ich bin ein Feind der "grands simplificateurs" und ein Liebhaber der Qualität, des Durchgeformten, Unnachahmlichen." Worte zum Bankett anlässlich der Nobel-Feier (1946), (1987). Gesammelte Schriften, Bd. 7, Betrachtungen/Briefe/ Rundbriefe/Tagebuchblätter, pp. (454), Suhrkamp Verlag, Frankfurt am Main.
} 

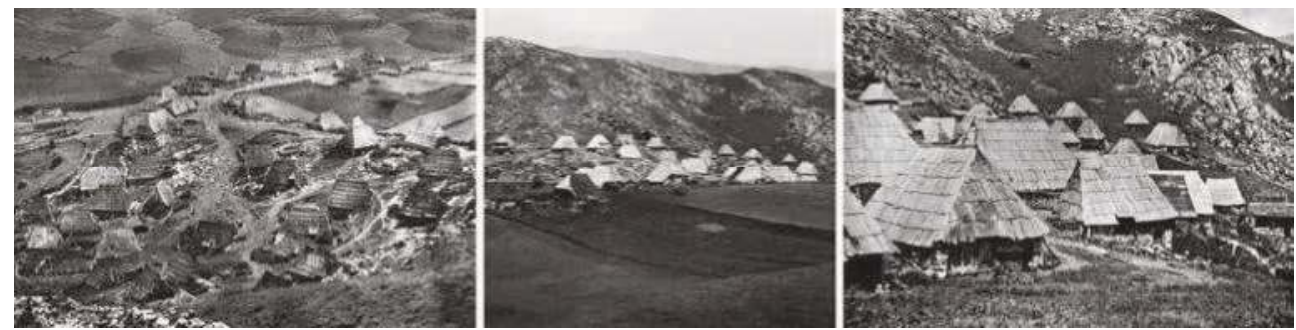

Fig. 1. Traditional Bjelasnica villages ${ }^{2}$

Speaking about global transformations that are omnipresent in physical, but also in spiritual sense, it is absolutely not to neglect the speed they have been happening. It is about every day, big changes being the consequence of the flow of information speed, thus, isn't it logical that, just through technological achievements that will be manifested rightly in architecture, this huge combining wave becomes the most visible and the most dramatic.

The expression of superiority towards invisible, adhesion, static forces has always been a symbol of strength and knowledge. Hasn't it been even in middle ages that secret brotherhoods had been established by those knowing the secrets of masonry and through them, the secrets of human existence? Respect of wisdom and preservation of accepted knowledge were given only to the privileged. It seems that nothing has been changed ever. The powers of those who knew to direct a vertical from the ground to the sky and who were able to maintain this vertical in static stability with no regards to the nature influences, were extremely appreciated. Thus, we may not resent the very process of rapid exchange of information, technological development having the goal of supporting human welfare and to technology which is progressing by itself because of the world capital which is directed to its development, for negative consequences of global development. We will easily state that globalization has the most negative influence to identity.

Today, there is no a priori respectable relation towards knowledge, probably because of the fact that levels of knowledge are reduced to the levels of information and the access to data basis.

Speaking about the globalization from the aspect of architecture, we are facing with very difficult task of estimating and clear expressing the fact whether it is about good or bad position of the architecture in global trends. Hadn't it been existing in the Roman Empire the global approach to architecture on the whole territory of big empire, but the goal was certainly clear, and in such manner the identification code of unique state was created Rome. Even later, when the universal style -modern was treated as the common attitude towards the architecture, there again, the message existed wanting to express modern and technological values present in twenties and thirties years of the past century.

What is especially warring in this historic moment is the fact that no matter to the information flow, technological values and all advantages of the communication systems, planetary idea, common denominator and global attitude are not recognized any more. Grandiose works became purpose in themselves. Ambience in which they are created is inferior in relation to contemporary interventions; there is no dialogue between the new and the traditional. Urban codes are no any more expressed in the space. Impressive Calatrava

2 Chabbouh-Akšamija, L. (2009). The Authenticity of the Rural Architecture as a Prerequisite for Active Protection; The Pilot Project Bjelašnica Village Ledići, Sarajevo. 
Bridge in Venice is the intervention which is evidently valuable and sensible towards the city but it imposes a simple question:"...is there enough space in Venice for two or more such bridges"? In the city in which the bridges and houses live unique story and create inseparable structure? It is strange that towards architectural value it behaves conceptual, that after the fact that the "form follows fiction" 3 where the ambience value is not relevant, it comes the moment when the mutual relation between facilities and ambience enter into conflict and compete between them. Accepting globalization as the result of time in which we live and analyzing correlation relation of facilities and their consumers in which sociological aspect dominates over esthetic one, in which the state of conflict is accepted as the expression of contemporary man spirit, the ethic component is neglected. It would contribute to harmonization between ambience and new projected part.

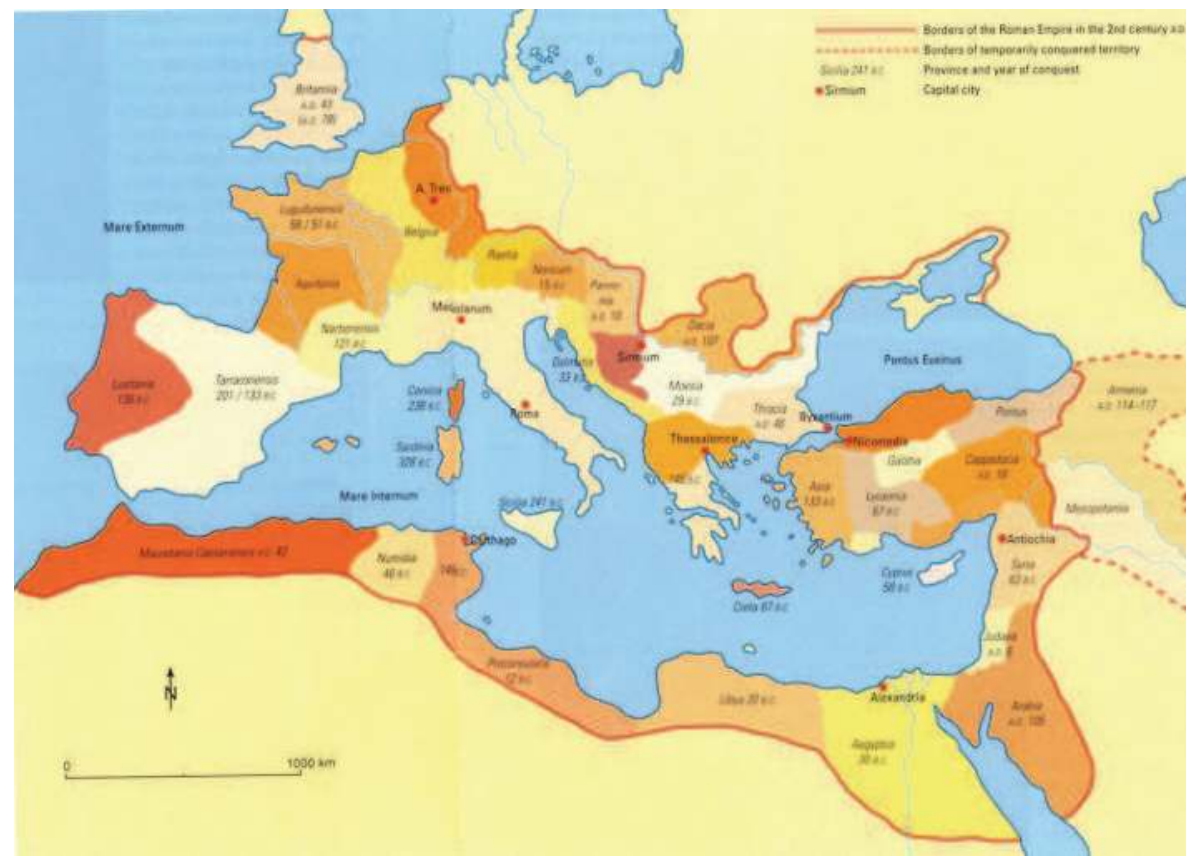

Fig. 2. Boarders of the Roman empire in $2^{\text {nd }}$ century A.D.

There is no field in human life that so directly influences the performance of living functions and flows such as architecture. I would say that it deals with the designing creation of the life wrapping material. Such hypothesis will logically bring us to the conclusion that the care on wrapping is reduced to appealing design, treating trends and being under big influence of fashion which is, observed from the aspect of visual culture, a global appearance.

It is not that I try to find the justification for the condition we are in, but it seems to me that the situation is not thus warring and that it is the period having its natural flow which is just passing by.

${ }^{3}$ Tschumi, B. (1976-1981). Manhattan Transcripts - collection of drawings and collages. 
I think that this phase may be treated as the phase of fascination and absolute impression by technology, and the respond to it is in absolute pacification and return to tradition. If we try objectively to valorize the actual condition on the global level in traditional manner and with determined criterions, we will enter into the trap that could be foreseen. Thus, we will valorize architecture as the piece of art. Is there, in such case, any possibility to objectively valorize a piece of art? Naturally, there is no possibility and naturally, the emotional deflection being unquestioned is the goal of the creator. The only things in which we may thoroughly follow the valorization are the parameters that are placed in accordance to definition of sustainability. It often seems to me that sustainability in phenomenology sense is placed so well in order to be the alibi for numerous failures that contemporary architecture in global surrounding represents today. Of course, it is about the economic theory entering into frameworks of sustainability sociologic, economic and ecologic aspects not treating those parameters which should be the most important for a valuable creation. It is not spoken about form, its measure, volume, proportion, materialization and details, neither about the function and traditional values.

I will conclude that globalization has extremely positive influences to architecture but universal, as the expression of uneducated and superficial approach, is the most perishable for it.

Given the acceptance that architectural interventions may be classified in relation to ambience to harmonized, contrasted and anarchic, it would not be difficult to conclude that the harmonized ones are rarer and rarer and that arrogance and superficiality in approach the most often, the trial of contrast turns into anarchy.

The process of globalization as the general and terrifying rapid process contains some other processes which by awkward interpretation in our surrounding reduce development as the positive category to destruction of tradition. Often, trials of stopping destruction of ambience and traditional values produce the reaction as it is a trial of stopping life. My modest judgment on globalization in general will stop on the statement that we, as the humanity, are caught by unexpectedly rapid flow of information, that we are not ready and without the attitude about the entity and integrity of space for which formation we need much more time than the speed of the information flow offers.

I will return to sustainability in which wing numerous negative manifestations of technological superiority find shelter. Analyzing social aspect, we won't be wrong if we focus to traditional values. Such angle will significantly change the aspect of ecology which will become inseparable part in treating the space. It is direct reflection of the ethic attitude of contemporary architect towards universal values of cultural and natural landscape.

It seems that we are in crucial period of the economic crises which will again result with global transformations in architecture.

The time of the architects "stars" has just passed by because there are no investors being ready to finance their spectacular ideas, and as the human needs to satisfy the existence issues with no matter to crisis may not be stopped, the time of the architecture for a human is coming again. In such case, respecting the continuity in deliberation and shaping of space, we have to turn beck to the origin and remind ourselves to solutions offered long before through the forms created inside individual civilization circles. In previous period, people got used to think globally and to search for universal answers to very specific and closely problematic issues, so we may expect global attitudes further more but this time based upon tradition and identity of local solutions. In this respect, my thesis that protection of architectural heritage is not only for the purpose of reminding to traditional values but also 
to serve as the inspiration for contemporary architecture and it may only have the sense if people at all do care about their own identity. Contrary to the universal in architecture there are identity, integrity, continuity and context. These four parameters define uniqueness and traditional values of ambience and each individual facility within it. It gives a possibility to the smallest local culture to express its characteristics.

In trying to find solutions for the unspoken questions, I stopped to traditional rural architecture of the mountainous areas, recognizing in it multi layer universality, with no matter to visible traditional values, on which, in any case, we have to insist. As we live in times of compromises in ideas and conflicts in realization, bringing such architecture into the context of contemporary urbanism, we may not reaffirm its values a priori. Still, if we stick to defining continuity in architecture, and make general bio-climate approach of traditional builders reversible through individual elements, then we will reveal, in this traditional architecture, completely new values. With risk to be subject to Romanism, and absolutely conscious of the fact that the greatest price to globalization was paid by small nations who didn't have neither strength nor money to fight against it in their efforts to preserve identity, today, perhaps, they have the greatest chance to find themselves in reaffirming their tradition through cheap and already tested architecture.

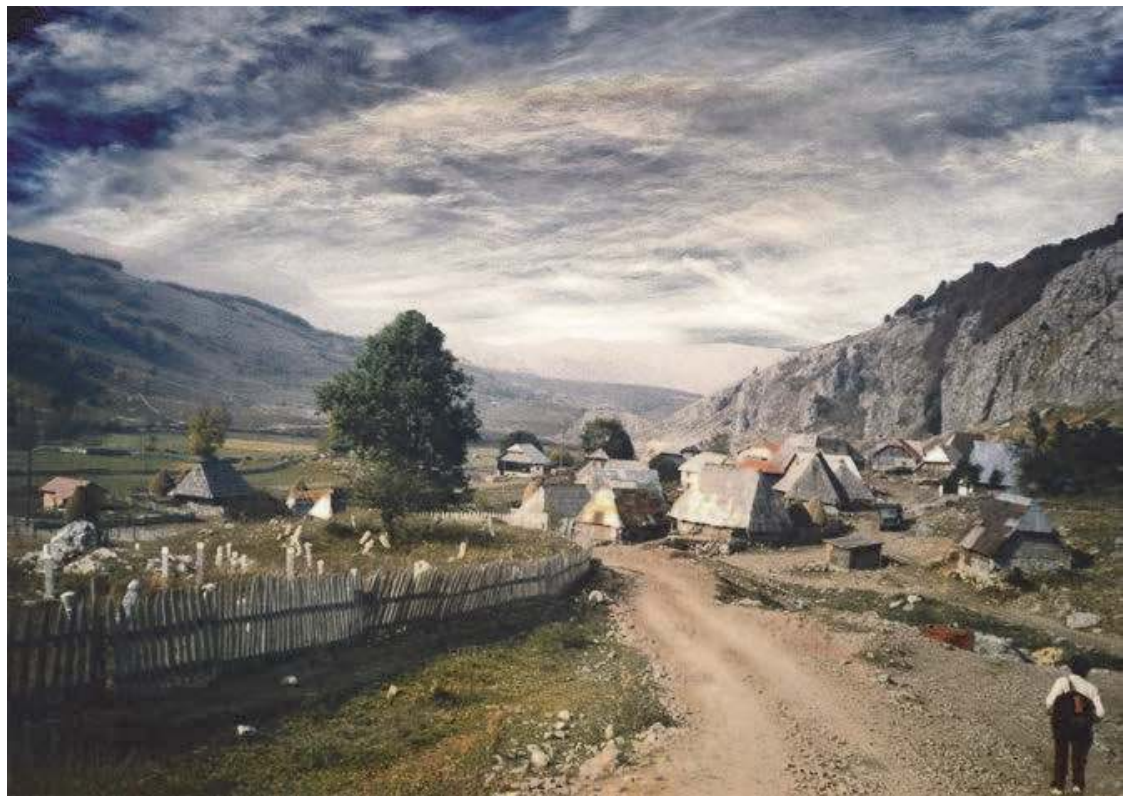

Fig. 3. Traditional Bjelasnica village ${ }^{4}$

\subsection{Background and goals}

However logical is the sequence of quoted facts on crisis, reaffirmation of traditional values and final resurrection of the space identity, it is hard to believe that the things may go this

\footnotetext{
${ }^{4}$ Chabbouh-Akšamija, L. (2009). The Authenticity of the Rural Architecture as a Prerequisite for Active Protection; The Pilot Project Bjelašnica Village Ledići, Sarajevo.
} 
way. Namely, to recognize traditional values in architecture, to undertake research of archetype form and to define the line of originality, in order to come to modern solutions that will stay in spirit of tradition, represent probably the greatest skill and privilege of the most sensible creators. Understanding the sense of invention has been always a part of my life attitude. For ones, its meaning is: to reveal something completely new, not seen before, while for the others, it is the revelation of the old and perhaps forgotten, but valuable.

It comes, from all perceived facts, that the protection of rural heritage value imposes itself as cultural, economic and social task of the first priority which should be one of the basic sociological, expert and scientific contents of action. Naturally, one should not stop to provision of material conditions for the protection of those values, but their survival in greatest measure should be connected to correct use with needed bigger engagement of all interested factors. The principle of such an approach to heritage is defined as an active protection, which, as the first element of procedure, points out the protection, but as the basic mean of directed projection insists on regular utilization of heritage.

Special interest should be directed towards rural ensembles, because it is about the spaces along which protection of architectural value of heritage, we protect also the ambience values of the landscape, meaning the natural heritage. In the time of the actual global warming and the lack of drinking and clean water, these elements get big importance in ecological sense. Whenever speaking about rural architectural heritage, we are facing with symbiotic juncture of the human and natural actions. Monuments unities should be a subject of special care in order to preserve their integrity, assure their recovery and arrangement, and through adaptation, to point out their values and adapt them to modern needs. Conservatory and restoration works on them should be performed in accordance to principles quoted in previous parts of the work. A term integral protection offers extraordinary advantages when talking about protection and the use of wider space in which the protection of ambience values is not under question and in those spaces where individual value of facilities is lower, so, by the concept of integral protection we give the importance to the whole agglomerations which value is exactly in the characteristics of unity. ${ }^{5}$

Finally, through all this analysis, we come to the question of authenticity which procedure of determination and the method of protection we try to identify by this work.

By putting numerous questions in trying to define "the right" and correct approach to heritage in contemporary life, we may not always come to solution. Responding to this question, we will try to develop the spirit of what was the content of the question. We may, with fear before the task, say that each of these questions is historical, fateful. It is historical, because it names the important in architecture, it names when and how the architecture may save and protect itself from the touch of the modern, sophistic mind having the reasonable explanation for all.

Cognition that the key task of the work is to question the essence from what has been questioned, explains that by questioning we will come to the source of what we want to think. Thus, it is about walkthrough into foundation, into pre-form, into the paradigm of the topic, being in this case the authenticity of the space in general.

The goal is certainly to turn back to originality and authenticity in the measure that such procedure will not disturb modern needs, but will use all forgotten knowledge that is

\footnotetext{
5 This attitude stems from the European Charter of Architectural Heritage, adopted by the Committee of Ministers of the Council of Europe on 26.9.1975., and Resolution (76) 28, on 14.4. 1976., concerning the adaptation of laws and regulations to the requirements of integrated conservation of architectural heritage.
} 
repressed by the arrogant modern man relying on technology and contemporary achievements in the extent in which the connection with seminal creator of time and space, nature, is broken. In this respect, bio-climate experiences overtaken from ancestors, the feeling of harmony between the natural and the constructed landscape and the use of traditional materials may greatly improve the quality of life today.

With focus to only one sequence of heritage, no matter how minor it is in general and overall world heritage, I will offer solutions that may significantly contribute to the general attitude that vernacularism and bio-climate of traditional facility along with ambience harmony, represent permanent value of constructed space. Sustainability and ecological awareness are the factors that lift to the higher level the quality of traditional facilities. Harmony that exists in such unison with natural surrounding is the greatest value that the constructor and the creator of space may expect. In aesthetic sense, harmony and unison with nature, adjustment of volume, materialization and proportions are the elements we estimate as highly valuable but from the point of view of the user such facilities are primarily functional, according to human measure, unpretentious and thus pretty.

\subsection{Methods of research}

The work applied original methods for the research and determination of authenticity having the goal to point out the importance of consciousness in relation to authenticity and originality of architectural forms in certain space in order to prevent the creation of false pictures on traditional values, and, in the same time, to provide clear cognition of those traditional values whose detection enables the placement of the framework for new projects and contemporary interpretation in accordance to the original ambience. During the process of research and documentation the method De Angelis d Ossat was used. Using quoted De Angelis method, specific methodological procedure was made in five phases, each one adjusted to specific needs of rural unities, devastated stone facilities and natural values.

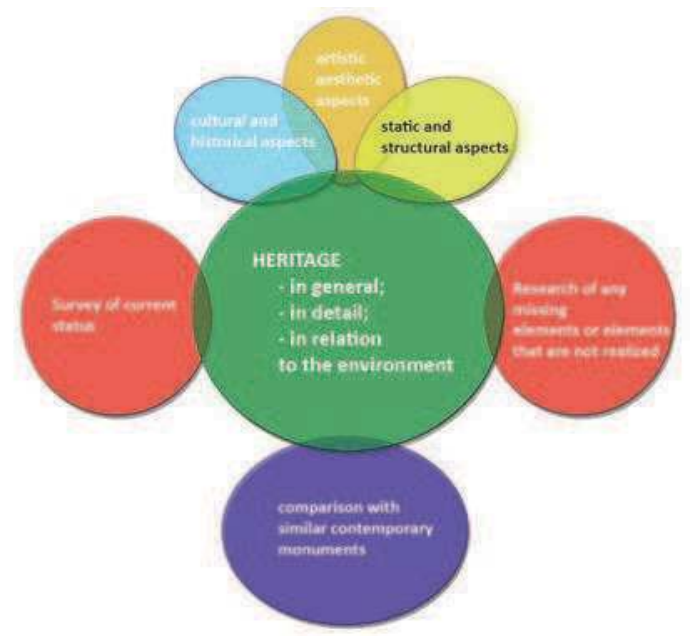

Fig. 4. Methodological approach De Anglis D'Ossat from 1974 - modified by author6

${ }^{6}$ Translation from the original: V. Sanković-Simčić, 2009. 
The First Phase:

DETERMINATION OF AUTHENTICITY (original situation)

- Research of historical data

Original situation of the location;

- Verification of original situation

Scientific analysis of the space transformation;

- Determination of authentic traditional values

Establishing limit of the cognition on traditional values about authenticity.

The Second Phase:

IDENTIFICATION AND TECHNICAL DOCUMENTATION (Status quo)

- $\quad$ Research on the ground

Status quo on the ground and the creation of photo data base;

- Identification and location on the ground

The look of the facility and control of basic graphic elaborates, including changes on the facility;

- Graphic documentation and technical drawings

1. Charts on the site as the mean for introduction and understanding of the facility or unities

2. Technical shooting and measuring Me.1:100, 1:200; 1:50; 1:20 (for details)

3. Architectural projects Me.1:100, 1:200; 1:50

4. Projects on Constructions and Details Me. 1:20.

The Third Phase:

COMPARATIVE HISTORICAL ANALYSIS OF THERURAL OBJECTST AND STRUCTRES (from the first and second phase)

- Historical iconocraphy;

- Comparative analysis of the same or similar buildings or complexes - similarities and differences

- Analysis of objects or complexes

- Historical evolution of structure

- Analysis of the materials within the time frame

- Constructive-restauration hypothesis about the possible interventions on the buildings or complex;

- Analysis of structure with characteristics details

- Analysis of the walls (structural)Analysis of different walls to set a hypothesis about construction of the facility and determine the authenticity

The Fourth Phase:

\section{ANALYSIS OF FORMS AND LEVEL OF DEGRADATION, PLAN OF DEGRADATION STRUCTURE}

- Analysis and plan of the main structural undertaking on the facility or on the ensemble;

- Identification of problems;

- Identification through graphic documentation (situation, basis, sections, façade);

- Plan of degradation on facades;

- Graphic study and analysis of the basic pathologic degradation in co-relation to different materials and mutual relations;

- Identification of the problem determined by the form of degradation;

- Identification of degradation on the external look of the facility or ensemble; 
Structural plan of the forms degradation:

Analysis of possible dislocation,

Analysis of structural displacement staggered on the wall surface,

Analysis of structural displacement inside facility,

Reading of pressure and of its influence on the example of the facility openings,

Cracks and fractures on inside wall surfaces, analysis for interpretation on mechanical characteristics of the building,

Plan and analysis of the principle surface pathologic degradation caused by different materials,

Plan and analysis of degradation of the composition values of the complex,

Plan evidence and removal of elements or facilities in disharmony with ambience;

- Analysis of degradation

Such type of analysis, used only for the facilities of exceptional importance, where, in the process of restoration, it is necessary to substitute lacking parts, certainly defines all used materials, but is rarely used because of high costs being result of the complex and specific process;

Prior to analysis:

- Activities related to collection of samples and their testing;

- $\quad$ On the basis of collected materials, selection is made with the work plan;

a. Testing of samples:

- Resistance of materials;

Laboratory testing:

- Mechanical testing of samples and explanation connected to mobile samples (blocks or quadrant)

- $\quad$ Testing in site

- $\quad$ Mechanical testing used by Marttineti platti ${ }^{7}$

- Module-metric verification using probe instruments

- Thermo-graphics as a general indicator for detection of holes or other types of non continuous damages in hardly accessible zones;

b. Chemical-physical characteristics of material

Laboratory testing:

- Chemical analysis

- Mineralogical analysis

- Weight and volume of materials

- Conductivity of materials

- Testing in site

- Testing of sediments.

The Fifth Phase:

\section{SCIENTIFIC RESEARCH}

Criterions for valorization and selected interventions;

Scientific elaborate of the protection of facility or ensemble;

Interventions: Project of structural conservation;

7 (1988). Indagine sulle strutture murarie del tempio cosiddeto di Romolo del Foro Romano: Prove non distruttive con Martinetti platti e analisi numeriche; pp. 16 (ISMES publ./1st sperimentale modelli e structure (Bergamo), No 237). Rossi P.P, Bergamo 
- Intervention on structural consolidation with project details;

- Intervention of protective restoration on facades;

- Project on architectural interventions;

- Project on urbanism interventions (at ensemble complexes).

This is a methodological procedure which flow is recommended as a methodology of the work in specific conditions of ambience valuable unities that have significant number of mutually similar facilities originating from merely same period and have similar stylish characteristics. Specific point of this work is the fact that the methodology is integral part of scientific research and a part of scientific contribution.

\section{Research}

\subsection{Determination of the originality line}

All previous classifications quoted through literature related to some of geographic, geomorphological, climate, ethno-religious, sociologic, demographic, historical and spatial characteristics that, as common denominator, connect or differentiate rural agglomerations. We often meet with the term Dinaric type of village which further on leads to South Dinaric and North Dinaric type. Those two types differ in their materialization because the South type is materialized in stone while the North one is characterized by wooden construction. Analyzing literature, it is noted that by now nobody has tried to identify Dinaric type with the way of Illyrian tribes disposition who populated these spaces of the Balkan Peninsula. Namely, these tribes, moving along Black see river basin from Asia, populated our territories and completed their movements in narrow path of the way to Poland. Following and marking this path, it is possible to draw the chart of village agglomerations who, as the roof cover, have maintain by today shingle, stone dray wall having the function of retaining wall for the house leveling, and wooden piles covered with mud and fold on quill at the wall construction of the house. Analyzing precious findings of the archeologist Borivoj Čović, who in the excavation of fort Pod near Bugojno found a house for which it may be stated that had the same elements. ${ }^{8}$ Čović mostly dealt with the Central Bosnia region and

8 Čović, B. (1983). Central Bosnia cultural group, In: Bronze age, Prehistory of Yugoslav countries IV, pp. (433-457), Sarajevo.

Čović, B. (1959). Trial Excavation on fort "Pod" near Bugojno, Archeological Review 1, Archeological Association of Yugoslavia, Belgrade, pp. (47-49); Čović, B. (1961). Pod Bugojno - prehistoric fort, Archeological Review 3, Archeological Association of Yugoslavia, Belgrade, pp. (51-52); Čović, B. (1963). Pod Bugojno - prehistoric fort, Archeological Review 5, Archeological Association Yugoslavia, Belgrade, pp. (3033); Ćović, B. (1964). Pod Bugojno - prehistoric fort of early and late Bronze Age, Archeological review 6, Archeological Association of Yugoslavia, Belgrade, pp. (23-24); Čović, Borivoj. (1965). Pod Bugojno prehistoric fort of early and late Bronze Age, Archeological review 7, Archeological Association of Yugoslavia, Belgrade, pp. (55-57); Čović, B. (1966). Pod Bugojno - prehistoric fort of early and late Bronze Age, Archeological review 8, Archeological Association Yugoslavia, Belgrade, pp. (23-27); Čović, B. (1967). Pod near Bugojno - fort from Bronze and Iron Age, Archeological Review9, Archeological Association of Yugoslavia, Belgrade, pp. (27-28); Čović, B. (1968). Pod, Bugojno - prehistoric fort of Bronze and Iron Age, Archeological review 10, Archeological Association Yugoslavia, Belgrade, pp. (25-26); Čović, B. (1968). Pod, Bugojno - prehistoric fort, Archeological review 14, Archeological Association of Yugoslavia, Belgrade, 1972, pp. (39-40); Čović, B. (1968). Pod near Bugojno - prehistoric fort, Archeological review 16, Archeological Association Yugoslavia, Belgrade, 1974, pp. (54-55); Čović, B. (1983). Central Bosnia Cultural Group, In: Bronze Age, Prehistory of Yugoslav countries IV, pp. (433-457), Sarajevo;Čović, B. (1987). Central Bosnia Group, In: Iron Age, Prehistory of Yugoslav countries V, pp. (481-530), Sarajevo; Čović, B. (1991). Pod 
concluded that complex and technologically advanced facilities from the late Bronze age appeared rarely in the Sarajevo valley, so, without reliable archeological findings on the forts localities on the Bjelašnica mountain it is difficult to state whether it is about early Bronze or Iron age. In order not to speculate on real traces and remaining of this culture in this accented space, comparative method tried to bring some hypothetic conclusions. A part of B. Čović description may be quoted:

“.. In good manner stratified material from Pod, along with material from other numerous fort settlements, provided a defining of Central Bosnia cultural unity of late Bronze Age. This unity, stretching around the upper and middle the Vrbas river flow (to Jajce) and the Bosnia river (to Zenica, this unity didn't include the Sarajevo valley), understood the independent cultural-ethnic community with clear characteristics of material and spiritual culture. Settlements of forts type located near bigger complexes of arable land and high level of housing architecture ${ }^{9}$ are characteristic for this community. Parallel to described settlements and characterization of housing architecture of forts type ${ }^{10}$, where population dealt with agriculture as the elementary activity, there are settlements of city type in mountainous regions and people dealing with cattle breeding. Contrary to settlements of city type located along the rivers with orthogonal and paved structure of streets, the settlements of forts type originated in mountainous regions are characterized by radial structure of streets. There is dilemma whether it is directed to different tribes whose approach regarding shaping was different, but it is positive that the primary activity of these compared city settlements differed approved by the selection of settlement location. Probably, the shape of street structure, population activities and manner of life are causally connected to climate.

Dealing with the phenomenon of architecture constructed by ordinary man, the architecture which by its form unpretentiously follows the function and construction supported by available knowledge and materials, that is with the appropriateness of the process of the space shaping, with no stylish characteristics ${ }^{11}$ as visual determinants, it is concluded that here we talk about the group of facilities which, through long period of adopted form existence, represent timeless value..$^{12}$ It is not odd that this type of architectural shaping kept so long the elements which, since their creation by now, have changed very little and only when it was conditioned by climate change or certain social circumstances that significantly altered culture of life. Certainly, it is about archetype of the village house that may be considered as the universal value of the first model which born plenty of modifications but

near Bugojno, Publisher National Museum of Bosnia and Herzegovina, Sarajevo; Decision from the Commission to protect national monuments, Official Gazette BiH, No. 75, (2008).

${ }_{9}$ Čović, B. (1983). Central Bosnia Cultural Group, pp. (433-434), Sarajevo.

${ }^{10}$ Čović, B. (1983). Central Bosnia Cultural Group, pp. (437-439), Sarajevo.

Scientific work of Academician B. Čović had important influence to the process of conclusion bringing in this Doctoral Thesis. Available data that were presented provided the removal of limits in examining originality and authenticity of archetype forms of the facilities constructed in this area, under which it is important to stress that the term form, we often use in defining traditional values, represents only one segment that we consider relevant for determining originality and authenticity.

11 Here we consider recognized and classified aesthetic values and physical characteristics of construction. It means - stylish characteristics $=$ classified forms of construction .

12 Under the term timeless value we understand characterization of those facilities that we recognize as the one and unique in corresponding time frame which have existed and which will exist as a product of the human work within the framework of adopted forms. 
always with the same bearers of the massage and the same common denominator (foundation, wall, roof...). For this research, based upon the searching for the authenticity of individual form of the facility, its proportion and materialization, and also for the authenticity of the unity, whether it is about the parts of the rural settlements or entire rural agglomerations, it is extremely important to find the archetype traditional value that would be a starting point for further development. In this analysis, it may be referred towards the integral heritage because the selection of theme clearly indicates that there is inseparable connection between natural ambience and those created by men's activities. In mountainous regions, each village has its characteristics. It is mostly connected for the position (location) of the village, for strong influences of the migration movements of population which are, on other side, directly connected to socio-political influences within certain historical periods. When analytically consider individual facilities, it is noted that the height of the window parapet was dimensioned according to the maximal height of the snow cover while the orientation of the windows was directed to the mildest wind and not to strongest insulation. The position of shingle placement is contrary to the wind direction. The facilities are regularly of rectangular rarely of quadratic form, but almost always with two sides exists on opposite sides, for the reason of snow, so that while entering the house it is not necessary to go around the whole house. The inclination mounts from 50 to 60 degrees because such spaces do not keep the snow. The houses are mostly located on steep terrains with the basement space, storehouse, serving as food storage or as a stable for small livestock. In such case, livestock through wooden attic construction warm by their own heat the upper floor thus participating in heating the upper rooms during the winter. Stables, as agricultural facilities, have the same concept of construction as the houses but only the under roof space is used for hay storage and this way hay is easily distributed before the livestock during the winters. Such facilities never have basement neither warehouse. This description with given conclusions that are presented in short review, refers to "The Nara Document on Authenticity", Conference on Authenticity in Relation to the World Heritage Convention, Nara, Japan, November 6, 1994.13 This document, from item 9 to item 13, treats problems of values and authenticity. Item 13 of the same document elaborates the things that may create authenticity:" Depending on the nature of the cultural heritage, in which we place its cultural context, its development through times, assessment on authenticity may be connected to great number of information. The aspects of information may include form and design, material and substances, use and functions, tradition and techniques, positions and locations, spirit and feelings, and other internal and external factors. The use of such sources provides the elaboration of specific artistic, historic, social and scientific dimensions of cultural heritage being examined.14 The speed of devastation of entire village agglomerations during the last twenty years, with special accent to the war and the post war periods when the massive degradation of these ambience ensembles happened, is merely non countable. There are many reasons for this and they primarily should be in the sphere

\footnotetext{
${ }_{13}$ Nara conference on authenticity in relation to the World Heritage Convention: Nara, Japan = Japon: 1-6 November $=$ November $1994:$ proceedings $=$ compte-rendu $=$ Conference de Nara sur l'authenticite dans le cadre de la Convention du Patrimonie Mondial / edited by = redacteur Knut Einar Larsen with an Editorial Group consisting of $=$ avec un comite de redaction compose par Jukka Jokilehto... [etc.]. Paris: UNESCO World Heritage Centre $=$ Centre du Patrimoine Mundial [etc.] , 1995

The Nara document on authenticity, 1994; whc.unesco.org/archive/nara94.htm; www.international.icomos.org/naradoc_eng.ht
} 
of sociology interest and the subject of their analysis. The task of he architects- protectors in this sense is, before complete ruination of these facilities, to record the referent examples thus permanently preserving authentic model of village house and village way of life. Ethics obliges us to consistency in documenting that may provide the faithful reconstruction or contemporary construction with reminiscences to traditional values of space. This approach is the least what the protection services may undertake considering the high level of degradation and the facilities which constructive potentials are such that the conservatory and restoration procedures are hard to be applied.

Looking from the opposite side, such approach to studying the authentic, village, mountain house and wider space it was located in, in the same time opens much wider fields of research, from ethnologic, over archeological to historic revelations of very origin of peoples who lived and who live on this territory, constructing not only original houses for living, but also today highly categorized monuments of culture, medieval tombstones, their eternal stone houses with inscriptions and massages of universal value. Out from historic analysis of population who lived on the territory of Bjelašnica and slopes of Treskavica it is concluded that that the first founded material traces about the life and permanent living of people belong to Illyrians. Resident houses created inside or outside the forts in typology sense belong to animal husbandry mountain house today, and a spiral of human stay on this spaces, long over 2000 years, brings to actual form of the house, thus putting a logic question upon the what paradigm of today's mountain house should be, that is, how it looked, what from and in what manner the village house from this region was built.

Previously made analysis offered three basic elements promising coming to the adequate solution. Those are, mostly, materials, measure, then proportion. Talking bout materials, essentially, it is about local and unprocessed materials found in the site, just on the location the facility is built on. It in the same time separates city from village architecture, because the city house is equipped by craftsmen by prefabricates, such as "ćeremit" for roof cover, non baked bricks in combination with wood for the house walls, carved stone for the foundations and similar. However, in the village, it is said for the hewn shingles ("šimpla" or "kaplama") as a roof coverage, about complete wooden construction of the truss and the walls, which, as an alternative, may have stone walls from the foundation to the roof, and in such case, not without reason, the facilities are semi-sunken using the natural terrain slope in order to get sufficient height in the very facility. About the measure it may be talked from two aspects, primarily as

- spatial relation of the facility and surrounding, in which the facility is mounting to maximal:

Basement + ground floor + roof with protruding rooms, and from another side

- volume of the very facility and relation of its elements.

The house volume has rectangular forms of the basis, with storages placed transversally in relation to the house in one half to one third of the ground floor surface, seldom placed longwise, in what case they are in two parts. The roof is in majority cases, as already quoted, under the slope of 50 to 60 degrees. The roof surface is, by its volume and monochrome material, dominant on the whole facility.

Regarding the proportion, the facility almost always has harmonious and mutually corresponding relation of different elements such as the cuboids of the ground floor and the roof pyramid. The mutual relation is in majority cases is $1: 2,5 / 3$ on behalf of the roof. It is difficult to recognize distinction between:

- the form as the product of heritage and tradition incorporated into all cultural values, and 
- the form as the result of the cultural conditions of the civil community which construct it and "technological" knowledge and possibilities of the national builders.

Authenticity, treated in this manner and reaffirmed through the Venice Charter, appears as an important factor in qualifying values. Understanding originality plays the basic role in all scientific researches of the cultural heritage, in conservation and restoration plans, and especially in the process of recording and listing that are used for the World Heritage List and other inventory lists of cultural heritage. Keeping to the basic postulates of the Nara documents on the authenticity, it is considered that the essential part is to define authenticity ${ }^{15 *} 44$ in order to maintain it in further processes of protection. In this regards, two segments important for authenticity were defined:

- determination of authenticity, and

- preservation of authenticity.

\subsection{Determination of authenticity}

As stated that authenticity of the facility or the ensemble a key for preservation and further use of the object and ambience unities, the procedure of determining authenticity and the procedure of the preservation of authenticity are extremely important for what is defined as an active protection. Elaborating these two procedures, the contribution of this scientific work may be also defined as well as its original hypothesis being confirmed through these conclusions.

Through process which led to authenticity as phenomenon category ${ }^{16}$, the procedure was established which could represent a part of methodology for determining authenticity. The first phase is documentation and recording of selected space. Using documentation from all available sources understanding old photographs, old notes, historical data, archeological data, etc., the data base was created which served as the starting point for further research. Using documentation and comparing similar cases, by method of common denominator, it is possible to determine archetype value of the form that could be treated as authentic form on selected space. Upon research-documentation phase, the work on the ground follows. By shooting and recording traditionally valuable facilities, constructive details and materialization of the facility would be determined. By taking samples in site, the starting point would be made for the final definition of authentic materials, and systematization of constructive details will give synthesis conclusions related to the use of materials for the sake of the creation of authentic forms. By checking the structure of facility and analyzing

\footnotetext{
15 "Authenticity represents a collection of important historic determined characteristics; from the original to the actual condition, appeared as the result of different transformations happened during the times".

International conference on Conservation Krakow, 2000, Available from:

$<$ www.terport.hu/download.php?ctag=download\&docID=4583>; The Charter of Krakow 2000 www.triestecontemporanea.it/pag5-e.htm.

16 Phenomenology is a philosophy method trying to create conditions for objective research of topics that are commonly considered subjective. It means, phenomenology deals with experiences and their structure such as explained by Edmund Husserl: Intellectually or scientifically judge on the things means to direct yourself towards the things themselves, that is from talking and opinion to turn beck to the very thing, test them in their self-givens and to remove all prejudices strange to them. In this particular case, authenticity as phenomenon category appears as a product of the path by which, starting from the phenomenon of pure intentional aspects of consciousness, we want to understand their immanent essence as the essence of the very things.
} 
materials, it is possible to determine the age and authenticity from the aspect of materialization. Taken samples on the ground through chemical processing and analysis of materials, may offer correct data on the age of embedded materials, which is specially related to facilities whose aesthetic and constructive value may not be valorized through the form. Besides, it will provide the correct use of materials, at substituting of the missing on the facility, in the process of conservatory and restoration undertakings, not jeopardizing authenticity. The process of determining originality and authenticity is continued through a comparative method where unknown and missing elements are being compared with known and similar (the factors of resembling represent the same geo-morphologic and climate conditions, the same period of appearance, the same socio-political and anthropological surrounding...) thus, the method of common denominators brings the needed conclusions. It was stated, through previous researches, that there are few parameters that are being valorized in the segment of authenticity. These are form, materialization and function. It is noted that the differentiation of two categories, form and materialization, helps to perceive the existing facility from the two aspects. The first category does not exclude the second and vice versa, but neither does it a priori accept. Here, the third category appears being the content or the function of facility. This category comes out from the first two but is not directly conditioned by them. It may be original or secondary or even tertial one.

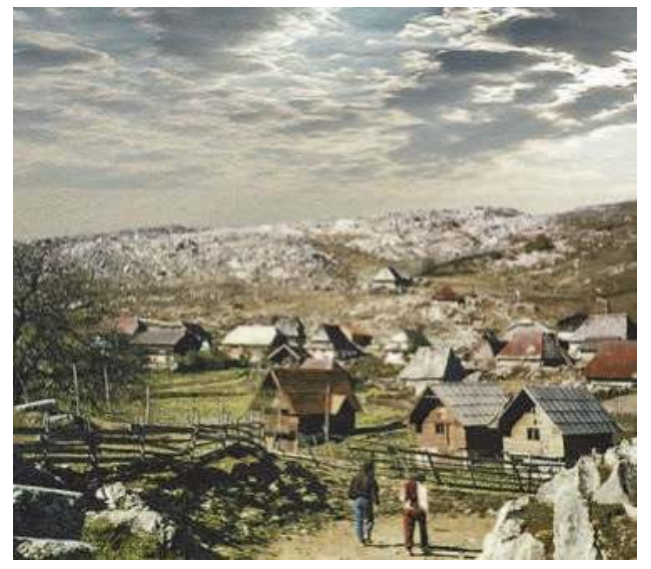

Fig. 5. Traditional Bjelasnica village ${ }^{17}$

- $\quad$ Analytic phase

a. documentation;

b. historical facts,

c. archeological findings.

- $\quad$ Research on the ground (Research of status quo)

a. recording

b. shooting

c. taking of samples

${ }_{17}$ Chabbouh-Akšamija, L. (2009). The Authenticity of the Rural Architecture as a Prerequisite for Active Protection; The Pilot Project Bjelašnica Village Ledići, Sarajevo. 
d. determination of types

e. valorization

f. method of common denominators as the sublimation of the researched.

- Synthesis work (directions for future work)

a. determination and defining of archetype form

b. determination and defining of the used materials,

c. determination of the facility function.

\subsection{Preservation of authenticity}

“... Those are precious witnesses of the past that will be preserved because of its' historical and mostly sentimental value; finally, also because some of them bear in themselves plastic virtue embodying the highest intensity level of human ingenuity. They are the part of patrimony of mankind and the people responsible for their preservation must do everything they can to transfer this noble heritage to future centuries". 18

Le Corbusier

Upon determining all defined elements that create authenticity, there is a complex process of preservation of authenticity. Often, extremely valuable unities disappear or are devastated because of neglect and the lack of consciousness about their value, but also, because wrong or bad planning of local community. This is why it is important to start the process of protection by inventory and valorization of the status quo. Parallel, through legislation, the ambience should be protected in the actual form and it is necessary to proscribe the rules for protection, maintenance and utilization. It is possible, through valorization, to define explicitly the fund of the facilities with traditional values separating those that jeopardize ambience of space. Often, the facilities making selected ambience unity are in the ownership of different private owners, thus, it is illusory to expect that the existing facilities being in disharmony with the ambience are removed or re-designed voluntary. The role of local community must be directed to bringing decision on paying adequate charges for not obeying certain measures brought in order to protect ambience unity and to bring the owners into position to voluntary re-design their facilities. It should also provide for new facilities being constructed to respect the brought rules and to be in ambience sense incorporated into the space. Naturally, romantics' concept of reconstruction, promoted by Le Corbusier 46, being for its own sake, became irrelevant in time especially when talking about village architecture. Using of reconstructed space and its proper repurpose, if necessary, revitalizes the ambience. The aspect of active protection gives to this approach full foundation being in accordance to modern economic and tourist tendencies. Through active protection and its application, prosperity and real application of today's popular sintagma "sustainable development"19 will be provided. The term sustainable

\footnotetext{
${ }^{18}$ Le Corbusier. (1998). Le Couvent Sainte Marie de La Tourette / The Monestery of Sainte... / Athen Charter, Paragraph 60, Arhitektonski fakultet, Belgrade.

19 UN Documents Gathering a Body of Global Agreements; Report of the World Commission on Environment and Development: Our Common Future Transmitted to the General Assembly as an Annex to document A/42/427 - Development and International Co-operation: Environment;

Sustainable development is the compatibility of nature, society and economy, that it is development that meets the needs of today, and that does not prejudice the ability of future generations to meet their own needs. In short, the concept of sustainable development is a new development paradigm, a new strategy and philosophy of social development.
} 
development deserves attention firstly because of the fact that all future planning has the support in theory postulates and international documents dealing with this topic. It is interesting that, when speaking about sustainable development, we mostly refer to environmental protection, although the UN documents on sustainable development deals with the protection of architectural heritage so, the General Assembly of UNESCO in its Universal Declaration on Cultural Diversities ${ }^{20}$, in the organization of Committee for Education, Science and Culture, treats the cultural heritage in the following aspects:

- cultural heritage as the source of creativity

- cultural goods and services: the goods of unique sort

- cultural policy as the catalyst of creativity.

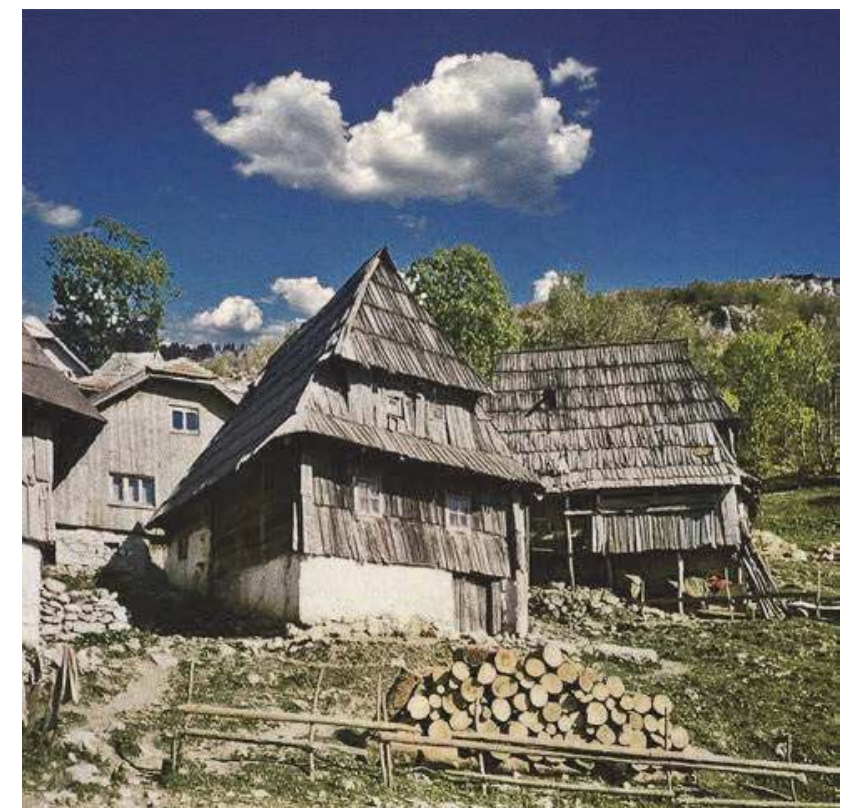

Fig. 6. Traditional Bjelasnica house - “čardak među rogovima"21

In the part describing the cultural heritage as the source of creativity, it is pointed out that the root of cultural tradition is in creation and that the tree blossoms in the contact with other cultures. Out from this reason, heritage in all its forms has to be preserved, stressed and handed over to future generations as the record of human experience and aspiration, in order to support creativity in all its diversities and to inspire the real dialogue between the

www.wiserearth.org/resource/view/.../section/gallery

20 UN Documents: Gathering a Body of Global Agreements; Universal Declaration on Cultural Diversity, Available from: <www.un-documents.net/udcd.htm>; Statement of UNESCO Director-General; Resolution of UNESCO General Conference; Universal Declaration on Cultural Diversity; Cultural Diversity and Creativity; - Cultural heritage as the wellspring ofcreativity; - Cultural goods and services: commodities of a unique kind; - Cultural policies as catalysts of creativity. unesdoc.unesco.org. ${ }^{21}$ Chabbouh-Akšamija, L. (2009). The Authenticity of the Rural Architecture as a Prerequisite for Active Protection; The Pilot Project Bjelašnica Village Ledići, Sarajevo. 
cultures. ${ }^{22}$ It all is a contribution to the hypothesis on the preservation of authenticity which is a precondition for protection, and especially active protection which will, by giving directions for the correct use of integrated heritage, provide the lasting and the renewed life of traditional values of rural architecture and its overall landscape. ${ }^{23}$

\subsection{Originality, authenticity, autochthony and identity 2.4.1 Phenomenology of original}

While discussing about traditional values, it is inevitable to discuss the notion of originality in the context of defining authenticity of the rural architecture today. Originality within the framework of this work is considered as the realization of the results of the natural growth of ideas emanated to conscious human activities (homo faber) that were directed to satisfying existential needs for quality settlement and life of an individual or a group in certain time period on the rural territory along with the use of locally available materials while constructing shelters. This process does not examine the origin of the very need for the creation of shelter, because this need appeared as a result of certain historic flows and technical-technological stadium of society development, as the answer to characteristic motive of geographic and natural conditions of space. Through research and determination of the originality limits, it is possible to determine the starting point of creativity, but, the conscious about the very beginning is unknown to its creator because it is about spontaneous creation happening for its own sake, and essentially, it represents only possible answer to the condition in which the national builder was found in so that even his final effect was not completely visible. It was created continuously in time and space as a unique and valuable contribution, by the mediation of national builder characterized by creational spirit for satisfying his existential needs. The value of such human activity may be characterized as duly and with purpose, but still, even personal (in the sense of the authorship) in relation to his creator. Definition of vernacular architecture is recognized here which represents the essential status of rural heritage. It is known from the history that the influence of such form of originality was continuous and coherent relation between the act and its' surrounding, integral, intuitively recognizable, and in intelligent and unobtrusive manner inwrought into natural landscape. Analysis of actual conditions of rural heritage brought us before the clear picture about non-existing, or mildly said, merely perishing of traditional values of the rural architecture on Bjelašnica. The appearance of preserved traditional values or originals in the context of integral values of traditional rural landscape is multi-layer and manifests itself in few forms. The first and generally present element in the scope of integral rural heritage is the natural landscape. Its presence in integral rural heritage is ultimate, although the focus of protection is mostly placed on constructed heritage. It is caused by the fact that this element is stable geographic category, which definition, providing it is determined as natural value, remains as a constant, except the actions to its ecological aspect. Not always the most dominant, but the most durable and the most stable parameter in the scope of integral heritage, natural landscape remains authentic and original in the original sense until it is exposed to modern interventions that produce its

\footnotetext{
22 UN Documents: Gathering a Body of Global Agreements - Universal Declaration on Cultural Diversity: Identity, diversity and pluralism; Cultural heritage as a source of creativity, Article 7; www.undocuments.net/udcd.htm.

${ }^{23}$ UN Documents Gathering a Body of Global Agreements; Universal Declaration on Cultural Diversity; Article 7.
} 
degradation. Danger for degradation of natural ambience represents non balanced use of natural resources ${ }^{24}$ at which the anatomization to renewable and non-renewable resources, understands that the use of renewable resources provides the existence in space, while the use of non-renewable resources permanently degrade natural ambience. This non desecrated space, defined as natural landscape in the integral value of rural heritage, and also individually observed values, although in semantic sense experienced and aesthetically valorized, is the essential bearer of the massage of original, traditional value. Aspects of observation of originality and the originals may be from philosophy, over ethnographic to this protective. Still, they all agree in one, that is, originality, along with origin ${ }^{25}$, authenticity ${ }^{26}$ and autochthony ${ }^{27 *} 130$, represent categories which for very long have not been status categories but the processes having two direction of movements. The value of these categories, in which, the level of society consciousness may be considered as the main characteristic of their conditions and status, remains constant providing no changes in the level of consciousness about them. Given the changes of the level of consciousness, depending on its growth or fall, its value in society proportionally grows or falls. All these categories represent the starting point of our existence and original traditional values and all meanings contained inside them, get or loose its value through time. It is not unusual when stating that there is forgotten knowledge, forgotten skills and by this forgotten tradition. Isn't it successive loosing of identity which in this existence leads towards deletion of memory and to globalization in all its most negative aspects?

\subsubsection{Four parameters of traditional value of heritage}

Speaking of originality, talking about heritage, we divide time to the period to massive industrialization and the time after it. We may with certainty state that massive industrialization destroyed crafts and made disappeared some previous knowledge and skills. New technologies brought practical and pragmatic, simple solutions, that replaced manufacture production of goods, but also construction. As the result, we meet the interventions on traditional facilities made in same materials, mounted in corresponding places but processed in modern manner, with no feelings and understanding for the original

\footnotetext{
${ }^{24}$ Hadrović, A. (2008). Bioclimatic Architecture on the Search of the Way to Paradise. Acta Arhitectonika et Urbanistica, Arhitektonski Fakultet u Sarajevu, Sarajevo, pp. (7-13).

${ }^{25}$ Under the term originality in the sense of geographic origin, we understand certain actions of man inside certain region, in certain place or, in extreme cases, in wider space, in maximally long time period which may be perceived as the most distant spot in relation to present time, along with evident use of composition-constructive possibilities and materials in order to satisfy the needs for defining own shelters.

${ }^{26}$ Under the term authenticity in the sense of valorization of engineering-construction characteristics of facilities in the times of their appearance, morphologic details, composition, characteristics and origin (in the sense of location) used materials.... We understand activity (construction; organization of the place of human existence), and appearance (constructed and designed forms), in maximally long time period that may be materially recorded in relation to the time of observation. Appearance as the integral part of authenticity we observe in immanent duality as spatial-event phenomenon (place) and shaped form (art effect).

${ }^{27}$ Autochthony is considered as extraordinary value of defined heritage which creates a collection of material and non material goods which define identity of observed element being placed in that defined space. This phenomenon, so as authenticity, is bound to the place while the originality does not have to represent the observation of the heritage in site, but it is discussed about its origin.
} 
work techniques, thus, the general picture is not adequate to authentic and original condition. It is great difference in relation to originality of material and non material heritage. Material heritage, such as art effect, may be protected in its original form or devastated by negligence and numerous, other causes of devastation. Each intervention on material heritage with a goal to preserve its authenticity, by incorrect approach in its unity or in its detail, may become the main reason for the loss of its authenticity. A term phenomenology 28 of original is chosen consciously wanting to give the importance and specific features to the sphere of originality which phenomenology binds to itself. May, then, the original be considered as a phenomenon? If, under phenomenon we understand peculiarity, exceptionality and rarity, then the answer to this question is positive. It seems that time we live in, consumers' society which does not accept exceptionality and peculiarity as virtues, brings the original and originality in question. There are few reasons for this, but economic aspect and speed of living are decisive while stating this hypothetic presumption. Turning beck to the concrete example of traditional, rural architecture on Bjelašnica, out from concrete conditions, it may be seen that the truth about originality and original without adequate status and that, while estimating their traditional values, it has already lost the battle with contemporary architecture. In any case, village heritage is considered original, and all changes happened inside it during the use and time passing, that did not jeopardize its authenticity, are considered as a part of their originality. Still, analyzing development of commercialization of these places, it will be stated that the appearance of tourism (here, it has not been transformed into cultural tourism) brings to certain articulation between traditional, rural heritage and the users of tourism offer. This all significantly influence jeopardizing of authenticity and originality, because in this articulation, pseudo models of traditional heritage, successfully replace real models which were replaced because of their frazzle or had been so reconstructed to lose their authenticity and originality. Now, all is being returned to the beginning of a discussion about originality (not only about originality, but also about authenticity, autochthony) where we stated that the society conscious about them is just the thing which directly influences their valorization. Thus, the users, consumes, have no general conscious on the original value, not

28 Phenomenology is philosophic science about phenomenon of world and life. The task of phenomenology is to determine, understand and make out phenomenon. It is preoccupied by phenomenon only, that is, by what is shown; its basic task is to place itself with understanding towards what is shown, to watch it and to try to explain it thoroughly, with no evaluation.

Phenomenon, Greek, (fainomai - we appear) according to definition: rare (exceptional) appearance (i.e. in nature); something famous; unusual case, miracle, rarity, exception.

Unfortunately, originality inherited by phenomenology of material culture is considered by the many people to be behind us, our needs and our time. Tradition, as originality, seems to be spent and useless. The things being of interest for actual creators of daily-political eventuality, including urban culture, come out from desire to suppress tradition and traditional and from wrongly understanding of the globalization of the rural. In fact, instead of originality, with new sensibilities, the new form appears: it is insisted on uniformity and on transfer of architectural experiences from cities into rural surroundings. See: Lancey,A.R.: Dictionary of Philosophy; Kruzak, - Croatian Leskovac, 2006

Phenomenology of original reveals the right sense of traditional rural: it is not unity of nature in ontological form but eternally changeable product of endless reflection defined by the need of homo sapiens to satisfy and provide shelter with available materials within the framework of traditional, rural forms; thus, original, rural architecture is transformed into phenomenon, into the content of this situation and becomes self-understandable horizon of the subject fact as it appears in natural attitude. 
even knowledge to recognize the original from the copy. It brings to the conclusion that heritage lost, if ever had in these places, a status of the subject in the story about values of space and indicates that determination and preservation of authenticity, along with the strategy of implementation of this valorization through public announcements, would contribute to better understanding and the acceptance of originality, authenticity, autochthony as real and nonreplicable traditional values with the aim of repeated finding and real understanding of the own identity. Especially when talking about rural, traditional heritage, it may be stated that it is timeless picture of Bosnia, unchanged through centuries and thus valuable and precious.

It, instead of the wars and divisions, must be coherent force that could gather groups of peoples around its own identity.

\subsubsection{Time and space in the function of heritage determination}

Given objectifying of actual rural heritage on Bjelašnica, through quoted four categories, approaching heritage through two dimensions that reflect stratification of the place the heritage was constructed in, time and space, it will be confirmed that the protection of traditional values has absolute sense. Originality of heritage, treated by this part of Thesis, sounds a bit absurd taking into consideration the term heritage ${ }^{29}$ which meaning incorporates originality as well. Still, concrete form of rural heritage on Bjelašnica, leaves under question the elements of authenticity and originality, not because there were some changes on the facilities, but because the original facilities completely disappeared or are in the phase of bed physical preservation. Objective condition of heritage leads towards the initial hypothesis of the work in which the authenticity (including the originality) is a precondition for heritage protection. Its stratified meaning structured through spirituality of authenticity, originality and autochthony, its physical determination created by empiric knowledge, inosculate in final appearance. Absence of any of quoted categories makes heritage desecrated for such dimension. Philosophers were, abstracting material component, talking about the relation of being and time. Para-phrasing, the facility may be treated as the being, that is its position in time today, it may be considered as the being with two faces, one turned to the past and the other towards the future. Those are two faces which, Borhoevski 30 , look to the past and into future, but will never be "face to face". They are in Heidegger sense existential/hermeneutic. They have not been given or have been given; they cannot pass because they are not anything substantial. Still, unfortunately, they are, substantial, and scientists occupied by reconstruction and protection of heritage, may not literally accept philosophic understanding of originality because it understand originality of spirit which is imperishable being not material. It is not limited by anything; it is an idea and a thought, free in time and space...

It is however necessary to mention Hegel words as the introduction of his work Phenomenology of Spirit:

"We do not know destiny, European destiny of spirit, but also the World one. We do not know any more to name God without entering fear and suspicion in it with no reason; we

\footnotetext{
29 According to definition: proves from the past, such as historic locations, buildings and unchanged natural environment considered as collective heritage of today's society; Collins English Dictionary Complete and Unabridged 6 th Edition 2003; William Collins \& Co. Ltd, 1979, 1986 Harper Collins Publishers 1991, 1994, 1998, 2000, 2003.

${ }^{30}$ Jorge Luis Borges, Argentina poet, essayist and novel writer.
} 
do not know to stop discharging an arrow which will, one day, fly towards somebody else seen as an enemy. If this idea, related to undermining of all values, would become a world's destiny, then, this unique human project reflected through the human appearance on Earth would really fail. We would bring into question the idea of evolution and the possibilities of the world and history. Along with this project I asked myself: Who am I? Where I would like to go? How can I get to know the thing about which there is no knowledge; how can I come to the cognition of social psychology? "31. These questions are key one if we want to talk about authenticity and originality. These are questions to which architectural heritage offers the answers. It helps in revealing the authenticity of spirit through the authenticity of the material, and, by determining authenticity and originality, to witness about the subject of research being the object and idea connected to its authenticity and originality.

\subsubsection{Identity}

Within the term of authenticity and originality, spiritual and material categories are contained. Terms autochthony and origin, there are the determinants of place and time of appearance, being existential determinants of facility, while the term identity ${ }^{32}$ we find the idea on origination, location and time. Only this parameter demands the analysis of the relation between the two dimensions that are in correlation, space and time. It was noted that the sense of identity, within the context of this scientific branch, may define otherwise in relation to general acceptance of identity as a determinant for heritage. Namely, it is necessary to turn beck again to complex philosophic discussion placing time dimension in relation to identity. In general, and according to mathematics theory, identity understands the sameness or the identical in comparison to two or more individual elements in the same comparative line. Still, talking on identical, or about the recognition of the same characteristics (trying to bring theory in the level of heritage), there is a question whether it is about the fact that the material value appears in certain time, then lasts and exists in each following period thus passing through time and space. Or may be the time factor is not relevant, thus, material values appear in one time, they last through the space, with no time as the factor? It is about two theories, a theory on endurance or stability or the theory on per-durance or per-stability.

We are interested in this relation of argumentations because it directly reflects the relation towards facilities accented by this work. Namely, if we apply so called Endurance theory ${ }^{33}$ to selected examples, then we may say that traditional, rural architecture stays through time and space reflecting in any moment its past characteristics of form and function from this time sequence. If we apply Perdurance theory, then it should be stated that traditional, rural architecture, from the time of its appearance, exists in the space, with no time characteristics, maintaining original characteristics only as the proof of the time of appearance. ${ }^{34}$ In actual

\footnotetext{
${ }^{31}$ Hegel, G.W.F. (1987). Phenomenology of Spirit, Introduction, pp.(17), Naprijed, Zagreb.

${ }^{32}$ According to definition: feeling of selfness providing equality and continuity in person during time: Synonyms: individuality, personality, exceptionality, uniqueness; (2009). Random House Dictionary, Random House Inc.

${ }^{33}$ McKinnon, N. (2002). The Endurance/Perdurance Distinction. The Australasian Journal of Philosophy, 80:3, pp. (288-306); Merricks, T. (1999). Persistence, Parts and Presentism, Nous, No. 33, pp. 421-438; Hawley, K. (2001). How thing persist, Oxford University Press, Oxford; Sider, T. Four-dimensionalism: An Ontology of Persistence in Time, Oxford University Press, Oxford; Lewis, D. (1986). On the plurality of worlds, Basil Blackwell, Oxford

34 Perdurance: theoreticians, such as places Quine, reject the attitude characteristic for the time of our natural communications. This attitude treats existing things of persistence and changes through time,
} 
discussions between supporters and theoreticians of these two directions ${ }^{35}$, the theory of perdurance has less and less supporters. It may be stated with certainty how the previous conclusion that traditional, rural heritage so as all material creations last through time and in each moment of its existence in space suffer from certain changes, today reflects the picture of all changes produced by passing of time in the same space. Heritage thus accepts the both dimensions equally, and the process of lasting exists as the basic parameter for its valorization. In this regards, going beck to the topic of originality, it may be stated that, when talking about rural, vernacular heritage, originality (thus authenticity as well) may be treated as a process of the changes on the facility, as long as the integrity of the facility is not damaged in widest sense. Even the process of violation of the physical integrity of the facility, as a consequence of the time passing, characterized as the aging of the facility, may (must be) treated as the originality of appeared changes. Contemporary interventions certainly are not to be accepted as originality but maintaining the facility in the spirit of time, appropriate to the unity of ambience, is a part of heritage for future. It has to be stressed that because of such situations, it is very important to determine the limits of authenticity and preserve it on the facility along with the respect of successive changes that meanwhile happened. At rural heritage, such cases where the visible changes appeared during the facility life time are very few, but at some monuments of higher classification value, it is the case. It is considered that the traditional values on the facility must be "readable" independently from the harmony of approach (styles) or specific materials. As by now, through certain theories or original conclusions, a status and reflection of these theories on all individual elements of integral heritage was tested, we will turn a bit to heritage that was already discussed in this work. It was previously concluded that natural heritage in the context of rural, integral heritage represents a factor of stability and consistency. Namely, it is rear the case that interventions in the past changed or jeopardized natural heritage. Such interventions are connected only to recent past and present time, treated as devastation and regulated through legislation and wider social actions. Concrete example of the Bjelašnica location by now hasn't had a transformation of natural heritage which would bring into question the originality or authenticity. Today, it is often the case. Such examples are noted on the places of quarry, at accented infrastructural network, which leave permanent changes on natural heritage as consequence. Originality and authenticity of archeological findings classified as sacral spaces, representing mostly necropolis of medieval tombstones, old Muslim graveyards with "nišan" (specific tombstone) and old orthodox cemeteries with crosses, were partly damaged by demolition and destroying but the biggest

but does not accept time, only space. Thus, the existing facilities rapidly differ from events or processes which enlarge its activities through time. One of the manners to describe position, when the perdurance theoretician is in question, will affirm that this theory negate the existence of different ontologic categories of existing things or materials.

Quine writes: “.. physical facilities, designed in four-dimensions in space and time, are not to be differed from events, or, in the concrete sense of this notion, from the process. Each is composed from simple content, but, heterogeneous characteristics of the parts of space and time is gerrymandered..." Quine,W.V.O. (1960). Word and Object, pp. (171), Mass: MIT Press, Cambridge; Zimmerman, D. Persistence and Presentism, Philosophical Papers, 25:22, Rhodes University, 1996, pp. (115-126).

35 David Kellogg Lewis (28.09.1941-14.10.2001) - American philosopher, John Jamieson Carswell (born 192) - Australian philosopher, William Van Orman Quine (25.07.1908-25.12.2000) - American philosopher, Alfred North Whitehead (15.02.1861-30.10.1947) - English mathematician and philosopher, Orlando Patterson (born in 1940) - American historian and sociologist of cultures. 
problem is dislocation of individual tombstones and moving and mounting of the "nišan" elements into the foundations and bearing walls of the facilities. Shifting from authentic location automatically brings into question the originality of these sacral spaces. Sometimes, it was done to protect these monuments but sometimes they represented obstacle for "development" of the space, or because of new spatial usable value. Anyhow, in this case, originality, needing a parameter of location determinant in site, may not be identified with authenticity because under this, we understand the condition of monument in the sense of its constancy and it doesn't have to take into consideration location originality, that is, autochthony. At the end of this discussion it is considered that, with no regard to distinction between these terms being almost versions (terms originality, authenticity, autochthony), they all together give determinants necessary for protection and renewal of heritage, corresponding mutually along with permanent correlation with time and space as dimensions always relevant for heritage.

\subsection{Rural heritage as bio-climate architecture}

When spatially framework for defining heritage was determined, mostly rural one, then the source for supplying construction materials was determined respectively. The principle of processing and installation of materials are reduced to primitive processing with formally simple constructive frames and essentially highly sophisticated and transferred to objective bio-climate and geo-morphological conditions of the climate in which it is constructed. In this sense, authenticity of materialization will be defined through geographic framework we are obliged to place, because, mutations of the same form happen just in the context of geographic framework with different materialization. We stress, that we do not refer towards archetype for which it was stated that it had dealt with authentic pre-form only, but to the authenticity and autochthony of forms and traditional values in the context of space. So, regionalization of territory, defined by different geo-morphologic and bio-climate structure, follows certain diffusion of characteristic materials in the specific typology of heritage. According to methodology proposed by Dr. Dušan Vuksanović36, applying method of bio-climate parameter analysis based upon previous identification and grouping of characteristic parameters, may be divided to:

- Bio-climate parameters - influences including conditions, reasons and motives

- Bio-climate parameters - answers including consequences and interventions.

Given the acceptance of such division to parameters of influence and answers to them, then, the sphere of interest is the answer/answers of national builders to conditions and influences of natural surrounding. Results of this research would then be focused to correlation relation of man and nature through creation of certain architectural solution as the answer to certain natural factors. Accented functionalism makes rural traditional

\footnotetext{
36 "Bio-climate parameters - influences made from factors of climate in certain location: climate, ground, relief, waters, vegetation. Bio-climate parameters - answers composed from architectural answers on the level of settlements and on the level of houses: selection of location, orientation, adjustment to topography, organization of space, materials and construction and finally typology of house and settlement". Vuksanović, D. (2005). Traditional Architecture as paradigm, Traditional Architecture of Monenegro, University Montenegro.

Faculty for Civil Engineering, Monograph, Podgorica, Retrieved from:

$<$ www.montenegrina.net/pages/pages1/arhitektura/tradicionalna_arhitektura-

_kao_paradigma_d_vuksanovic.htm>
} 
architecture extremely bio-climate. Rural architectural heritage, as the expression of bioclimate architecture, is absolutely adjusted to climate on which was constructed shown through the heritage of the Bjelašnica mountain.

\subsubsection{Harmony of relations between rural and natural heritage - view from distance}

In semantic analysis ${ }^{37}$ of the space observation, the first to be noticed is the harmonious relation of natural landscape and constructed rural heritage. It is visible that measure and proportion in the relation of elements in rural heritage are harmonious and that ergonometric metrics used while dimensioning facilities, corresponds to natural and harmonious relation inside landscape of differentiated natural and architectural heritage. Analyzing further on the position of facilities in relation to terrain, it may be stated that the settlements were constructed regularly in the places where bio-climate influences were extremely positive. It is noted that the factors of insulation, winds circulation, water streams, sources of drinkable waters, vicinity of arable land...directly influenced the selection of location for the construction of settlement. This phenomenon is noted at transformation of rural settlements during the times, while enlarging, where obtained relation of space was maintained so that the stretching of settlement was directed regularly following the location of the first houses. In such way, mountainous, dense settlements were created and amphitheater position conditioned careful preservation of fertile land so the facilities were placed one behind the other while the plane was kept for processing. It was often that, because of specific features of terrain, the fertile land was not inside the village space thus bringing to the conclusion that while selecting location for the village construction along arable land or position that would satisfy bio-climate conditions, by existentially clear preference, the other solution was selected.

\subsubsection{Harmony of the relation between rural and natural surrounding - view of the proximity}

Observing position of traditional, rural settlement in relation to natural landscape from proximity, harmonious relation between materials used for construction and elements that were materialized with surrounding, will be noticed. It is exclusively about natural materials found in site so the facility interpolation into surrounding is clear. Besides already noticed values of measure and proportions, materialization contributes to specific mimicry of individual facilities and then rural, traditional settlements into natural surrounding. Installation of materials and their processing are part of knowledge about nature of materials and their characteristics. Constructive frames created for the sake of certain sustainable forms, being the answer to natural conditions of space the facility was constructed, are part of traditional knowledge or, as already stated, of intuitive knowledge.

\subsection{Facility details in relation to bio-climate parameters}

Analyzing contour of rural, traditional mountain house, multifaceted forms of each single element were found. The most often and almost ultimate premise of each housing facility in

\footnotetext{
${ }^{37}$ According to broader definition, semantic (the word originates from Greek semantikos or "important meaning" extracted from sema, sign) is a science examining meaning. It gathers perception, identification and interpretation of signs of certain disorder and serves as a synonym for symptoms. Common modern term for studying non verbal communication is harmonious relation of natural landscape and constructed rural heritage.
} 
traditional Bjelašnica villages is to be constructed on slope terrain. This, in multiplied manner, simplifies construction because the terrain is leveled by construction and not by digging considering difficulties at digging stone terrain; this way provides the space for small cattle breeding and their presence during winter time warms the space above storage.

Semi-floor being a floor from one part and from the other ground floor, having been built depending on geographic framework and geo-morphological characteristics from wood or stone, and later from "dizma", has unusually low height conditioned by impossibility of quality isolation of walls. Slope roof surface offers possibilities of bigger space volume for inside use but also as the answer to natural influences cause by precipitation and big number of snowy day annually. Wide eaves, sloped deeply towards the ground, serves as the windshield and shelter from snow.

It will be concluded that all quoted elements were in good manner adapted in the sense of the answer in relation to bio-climate parameters placed before rural heritage as conditions.

\subsection{Empiric and tradition checked through contemporary methodological approaches}

Observation of rural unities of the Bjelašnica Mountain leads to the thought that national builder had infallible, by experience obtained skills which resulted in form and in house construction. Talking about heritage, form and construction belong to traditional values of facility. What is indisputable, and may be considered as superstructure of the firstly mentioned fact that, final result, authentic village house and entire ensemble unity of village, reaches the level of mind message. It is what message?

Overall harmony with natural surrounding is in question. Neither element is in conflict with natural parameters. It is wise decision of national builder not to fight and jar with nature because they are in advance lost battles. To the contrary, harmony and unison in selection of materials and form led to the fitting in correlation of elements with entire house, the entire house with whole ambience and ambience with natural surrounding, so as of all quoted elements with each other and with all natural parameters. Such network of correlations speaks about the conscious need for adjusting not confronting. It is not about the conscious which led to formal harmony, out from purely formal reasons, but about existential need for survival, for lasting in these selected spaces and for searching the best manner for harmonizing needs and reality of existing in hard living conditions. Each of individual elements that may be recognized on the facility, if anatomized to constructive elements, is the bearer of the message about technical possibilities and real, sustainable values. Starting from the foundations which are only stone force supporting walls, adjusted to stone structure of ground being hard to dig and cut but solid enough to bear wall construction. Thus, all these facilities look like broke out from terrain without artificial horizontals of ground with terrain lines reflected in contour and not contrary.

Wall cover (mostly stone) by its mass, $50 \mathrm{~cm}$ thickness on average, with two sided masonry and lime mortar improving the solidness of wall, is the best thermal isolator in inconvenient time conditions. The size of wall openings is adjusted to technical possibilities thus no opening overpasses width that a $5 \mathrm{~cm}$ thick board may not bridge. In the same time, small dimension of windows disables loss of heat energy during winters, and heating from outside during summers. Parapet of the window is never lower than average height of snow thus the windows on different house sides are from different heights depending on the position of the facility in the village, or differing from village to village conditioned by micro-climate parameters. Generally looking, the windows on Bjelašnica are rarely open towards South because of strongest wind coming from there. Roof construction is slope, covered with shingle 
wrought one for another thus making monolith coverage from inside supported by horns with struts. This construction behaves spatially as harness series of linear grids so each frame of horn and struts represents single bearer and mutually they are connected by irregularly nailed boards from inside and with shingle from outside. Because of strong winds, very few facilities have chimney. The smoke from the house goes out through under-roof space ("badža"). Construction between floors is placed into the stone wall transversally and the beams interlocked to 2/3 with wedge-shaped strips placed into grooves thus increasing firmness and tension of the whole ceiling construction which behave as a board.
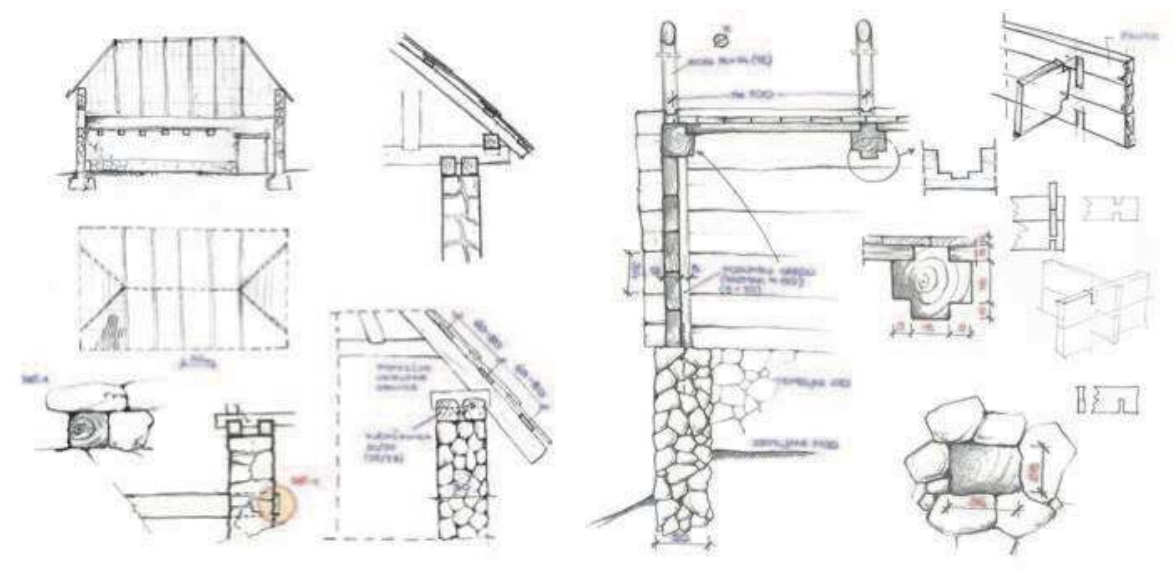

Fig. 7. Drawings of roof structures 38

The review of elements speaks in the favor of thoughtfulness of each detail and further researches would bring to the conclusion that from constructive aspect there is no better solution within the context of using traditional materials for these purposes.

Actual position of constructors provides, thanking to technology, to overcome obstacles, but often, there are consequences of these mistakes that appeared by bad application of that technology. Sometimes it looks that technological domain is its own purpose. So we again turn beck to historic facilities which in previous text ${ }^{39 *} 153$ were named architecture of vanity, so it seems that such phenomenon in architecture appear in cyclic and after them, each time, there is new time for cognitions.

\subsection{Ecologic aspects of materialization of rural heritage facilities}

Context of bio-climate architecture may be considered in solid relation with already defined integral heritage or with integral values of space. Stating that rural heritage is bio-climate architecture, it was also stated there is unbreakable connection between constructed heritage and natural surrounding understanding natural heritage and even the connection between sacral spaces inside integral heritage and its overall surrounding. With this harmonious solution of space, it was not considered about ecology but today these mutual relations of quoted elements of integral heritage represent ideal in ecological sense.

\footnotetext{
${ }^{38}$ Chabbouh-Akšamija, L. (2009). The Authenticity of the Rural Architecture as a Prerequisite for Active Protection; The Pilot Project Bjelašnica Village Ledići, Sarajevo.
} 
On the Bjelašnica Mountain, the eruption of new constructions in its central part brought to significant ecologic disharmony as a product of casual disrespect of basic ecological presumption regarding the use of traditional materials and volumes adjusted to such ambience. Here, the feasibility and need for traditional rural construction is recognized. To the contrary, actual modern construction, use of new materials, with questionable ecological value, and above all, big volumes radiating energy thus by its heat radiation danger microclimate of the location, brings to statement of how new builders rapidly destroy natural values of ambience. It will be concluded that manifested bio-climate value of rural heritage may be characterized through three elements of reunion:

- Synergy, as mutual and synchronized action of bio-climate parameters of influences and answers which contribute to the creation of ecologic ethics and where each parameter is inseparable, integral part of another one.

- Synaesthetic which, by perception of space, confirms that the sensible feelings of individually perceived elements of integral heritage, is much lower from the feelings of totally perceived space. Thus is an element of reunion which activates memory, experience, space and time for its evaluation incorporating form and structure of heritage so as aesthetic values of landscape.

- Synchronization, no matter to our preferences, heritage may not been considered as unique entity in space; it has to be estimated as inter-action of all factors in bio-climate process so that bio-climate parameters of influence may be considered relevant for the shaping of parameters of answers. But, given disharmony in shaping the parameters of answers, they would probably be responsible for changes of parameters of reasons. This is never the case with architectural solution of traditional rural heritage, but this parameter is important for the evaluation of its value in relation to contemporary architecture at these spaces. Ecologic aspect is considered as on of the most important attitudes while valorizing heritage, but it is also the most important factor while creating the concept of the use of space and sustainability of its concept of use.
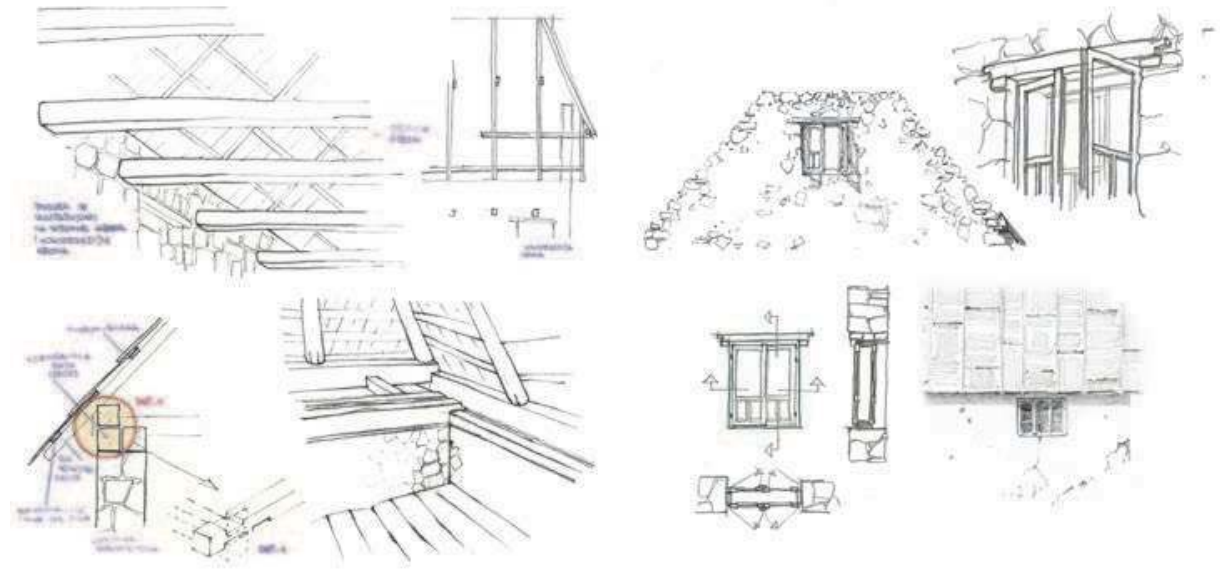

Fig. 8. Drawings of structural details ${ }^{40}$

\footnotetext{
${ }^{40}$ Chabbouh-Akšamija, L. (2009). The Authenticity of the Rural Architecture as a Prerequisite for Active Protection; The Pilot Project Bjelašnica Village Ledići, Sarajevo.
} 


\subsection{Causality}

It was already stated that on the Bjelašnica space, one type of house is mostly seen which is materialized in different materials depending on geographic framework and under which geo-morphologic characteristic it was created. Dispersion of "Dinaric" semi floor house ${ }^{41}$ speaks about causal connection ${ }^{42}$ between location and type of construction but also about similar constructions on different locations. "Typical natural conditions result (principally) with typical answers and differences in answer are the results of differences in social conditions (historical circumstances, cultural influences...) 43 $^{43}$

Analyzing this similarity we come to an archetype form of the house and its origin and traditional architecture, or, we turn beck to placing boundary of originality as the constant value and technique of construction that have been developed and substituted through times. Reasons of this "unity in differences" are in unique contents of integrated housing and economic needs in rural surroundings so as in uniqueness of architectural philosophy: approaches, concepts of space and procedures in construction which no matter to differences (caused by differences in natural and social conditions) express more common elements in the sphere of establishment/construction of space. ${ }^{4}$

\subsection{Sensibility of peoples' builders for compatibility of integral heritage}

Although stated that on the Bjelašnica territory a type of semi floor house is perceived, this model varies from village to village not only in materialization but in plenty of variants stating that peoples' builders relied on their founded cognition about construction, using manual processing of materials (significantly contributing do diversity because there is no possibility of copying) and with unmistakable feeling for space and context, created values with expressed personality and recognizable features. ${ }^{45}$ In the Chapter related to the Ledići village, it will be explained on concrete examples. "Functional concept, construction, shaping of unity and details, or, all phases in construction procedure of peoples' builders, from the selection of location and position of house on the terrain up to details of eaves and openings, are subject to severe logics and functional demands. Through long-lasting process of improvement and selection, certain patterns that are used in creation of architecture were formed resulting with simple and practical solutions (as it couldn't be otherwise) and corresponding aesthetic. ${ }^{46}$

${ }^{41}$ Dinaric semi-floor house represents a term we consider more appropriate from the term "Dinaric log cabin" not considering this wooden variant of this type a priori older nor more important. This term in better way explains characteristics of facility giving possibilities of more clear definition with additional adjectives of stone, wooden...

42 One of the main legality in nature is causality, and we don't see causality from independence and connectivity. Causality presumes relation between accidental variable which is the reason and an accidental variable being the consequence.

43 Vuksanović, D. (1998). Traditional Architecture of Montenegro and bio-climate, Monograph, Fund Andrejević, Belgrade, Retrieved from

$<$ www.montenegrina.net/pages/pages1/arhitektura/tradicionalna_arhitektura-

_kao_paradigma_d_vuksanovic.htm>

${ }^{44}$ Krainer, A. Equality in Variety - A Review of Bioclimatic Growth of Buildings on Yugoslav Territory, Proceedings in Variety of Fifth International PLEA Conference - PLEA'86, Pecs, 1986.

${ }^{45}$ Bobić, M. (1994). Ecotechnologic aspects of architecture, pp. (79-89), De re Aedificatoria - Architecture and Technology, Belgrade.

${ }^{46}$ Vuksanović, D. (2005). Traditional Architecture as paradigm, Traditional Architecture of Monenegro, University Montenegro. 
Concluding this discussion, it may be concluded that, in the process of active protection of rural integral values of space, aspect of shaping, materialization and construction must be multiply analyzed in order to maintain traditional values of that space. This analysis has the goal to direct new construction with its conclusions giving all relevant parameters necessary for its correct direction.

\subsection{Cultural heritage as the source of creativity}

Despite definition of creativity understanding complex mental process, including creation of new ideas, notions and problems' solutions, this phenomenon may be regarded as the engagement on the creation of new connecting lines between existing ideas and notions. In this regards, not neglecting traditional values expressed through authentic forms and functions, through new approaches to existing values, keeping the spirit of traditional space, exceptional, contemporary creations could be realized. It is certain that this, almost empiric, methodological approach of contemporary interventions within traditional space is the heaviest possible task. Assumptions that one may relay on the sensibility of an architect, may not be decisive for bringing decision on giving absolute freedom while creating new facility. There are two dangers. One stating that because of ignorance there are actions in space with facility of contemporary expression, with measure, proportion and materialization that could degrade overall ambience. The second is that contemporary facility appears in the form of replica imitating traditional form but represents false document about the time in which it appeared in the expression that could not be treated as creative. Thus, it is necessary to place the framework, sufficiently solid not to leave dilemma on traditional values incorporated into new facility regarding the context of integrity, but flexible enough to leave space for creative action. Preservation of integrated values of space depends on definition of directions for construction inside traditional unity. This approach gas the goal to act with inspiration, accenting traditional values as the inspiration and significant intuitive potentials, subliming all previous knowledge, but foremost the experience. It is not a priori about the use of traditional techniques, and consequently about traditional technology. This segment is regulated by specific rules in the implementation of the methods of protection. It is obligation only in the case of the existing of the facility which is recorded, protected by legal regulations and demands adequate protection by conservatory-restoration methods. In the case of new value creation in the scope of traditional and valorization of landscape, the use of traditional values through recognized forms, materialization and volume, gives unlimited possibilities.

\subsection{Tourist potentials of the Bjelašnica Mountain}

Biologic qualities:

- High diversity of vegetation from low to high altitudes

- Rare habitat or plant species

- Huge number and diversity of species

- $\quad$ Big number of endemic species

- Big number of jeopardized species on national, European and international level

- Significant presence of the main species

Faculty for Civil Engineering, Monograph, Podgorica, Retrieved from:

<www.montenegrina.net/pages/pages1/arhitektura/tradicionalna_arhitektura-

_kao_paradigma_d_vuksanovic.htm> 
Quality of landscape:

- Exceptional samples of traditional mountain landscapes as result of traditional system of raising

- Under average panoramic mountain spaces;

- Large spaces with impressive canyons

Geomorphologic qualities:

- Fantastic canyons

- Wide network of underground caves

- Glacier elements

- Exceptional samples of karst elements

Eco systems:

- Protection of water supply for Sarajevo

- Protection of soil from erosion

- The offer of recreation areas for the population from urban surroundings

- Provision of woods for local wood industry ${ }^{47}$

\subsection{Types of facilities on the Bjelašnica territory}

\subsubsection{Traditional rural architecture of Bjelašnica - vernacular architecture}

Recognizing specific values and characteristics of rural Bjelašnica space, we may state with certainty that this architecture, on few basis, may be considered vernacular. It is stated that the basic type of facility is recognized which may be classified into dinaric mountain house and differed into two sub-types, South type: dinaric stone house and the North one: dinaric wooden house. After, it is stated these types and sub-types differ village to village, that they have their own specific characteristics differing them by the form of facility and materialization from other facilities in this wide territory with dispersed dinaric type. But, they always maintain basic traditional values of architectural heritage of the climate they belong to. These traditional values presented through form, construction materials and function, are the complete answer to the climate, climate conditions, geomorphology and other parameters of the space they are placed. Besides these facilities, representing permanent settlements of people, there is one significant number of facilities intended for temporary sojourn out of which the biggest and the most significant is the locality of the village Gradina representing cultural settlement, summer village of cattleman.

Why there are three basic types of facilities for housing and temporary sojourn on Bjelašnica territory? The answer is in precisely defined landscape, where North-East side is richer in woods, and South-West one in stone. On North-East we find houses for temporary sojourn "katun", being completely constructed in wood and combination of wood and stone. The second reason is that on the South-East side the indigenous remained while the South-West slope, by migration of population at the beginning of XX century, was populated by inhabitants that previously lived in South parts of the Balkan Peninsula and who brought with them their tradition and habits to this region. They brought new type of facility named as stone floor house significantly differing from the type of "čardak" between the roof beams which was most common in this region. Characterization of types is not only a picture of materialization of traditional values. It helps us, through typology and transferred traditional values, to get knowledge on sociologic structure of village. The first type is

47 Žeravčić, G. et al. (2008). Master Plan for the development of rural eco-tourism in the area of Bjelašnica, Structure and content of tourism, Sarajevo, pp. 71-101. 
"katuni", shepherds' habitations whose settlements almost disappeared from the Bjelašnica territory. Only habitation on Gradina near Umoljani has been preserved by now. The other type "čardak between roof beams", extrapolated from archetype value of dinaric house, was materialized in stone and wood. Stone type of "čardak" survived only in few villages being mostly devastated $\mathrm{m}$ while the wooden form of this type completely disappeared from Bjelašnica. It is interesting that just this variety of "čardak" was characteristic and unique form of Bjelašnica region and his appearance was connected to late eighties and early nineties of the past century witnessed by numerous photo-documents and available archive materials. Original type of stone semi floor house with no "čardak between roof beams" is considered as older type of "čardak between roof beams" being connected to medieval construction as original determinant. The third type placed on locations populated by emigrants from Montenegro, a type of stone floor house, with no regards to imported form in materialization, is very close to previous quoted types. Transformations performed on this type, from original to the Bjelašnica local realization, are directed mostly towards construction solutions and materialization of details. Such solutions are considered as the influence of local traditional values, but also the closeness of original types which boundary of originality, and even boundary of authenticity, is common.

\subsection{2 "Katun"}

Example of "katun" settlement is village Gradina above Umoljani. Toponym Gradina represents primary archeological source in the form of pre-historic finding from Middle and Late Iron Age. At this location Illyrian well and traces of habitat were found and according to Borivoj Čović a fort, in wider sense, represents each finding on dominant position with fortification built from durable material, while in narrow sense, fort is "all places of permanent sojourn of smaller of bigger pre-historic communities which, by the very geographic position, offered certain level of security from abrupt attack; possibility of control and perception of closer surrounding; conditions for defense organization." 48 . On this historic location a habitat exists composed of 43 "katun" 49 which, by their summer time use (summer time of pasture), represents habitat of the Herzegovina cattlemen only in one part of year. Facilities that preserved their traditional forms and materialization were purposed for summer time use. Although they all have openings on the roof for the smoke because somewhere there are still open fire places which today were replaced by stoves on solid fuel used for thermal processing of milk. Settlement is oriented towards unlimited pastures for cattle (cattle feeding) with some facilities and fenced spaces (cote). Structure of facility is two floors on horizontal and a single floor vertically.

"Katun" is placed on stone drywall which, depending on terrain configuration, may be from $1,7 \mathrm{~m}$ height, mostly when speaking about facilities placed vertically to slope. Ground floor is from wooden mass, in variation from wooden boards, connected "on feather" from braiding covered with mud, mostly on the front wall which may be covered with tin or shingle. Roof construction is with struts, visible from the ground floor room. Used wooden material in roof construction is not or only partly processed. Slope tent roof has the inclination of 45 to 60 degree, and the side or the cross walls are bearers for the roof window

48 Čović, B. (1965). Gazette of National Museum in Sarajevo, No. 20, pp. (29-30).

${ }^{49}$ This term is related today to the type of facility and before was a determinant for habitats created by Vlasi in medieval Bosnia. Vlasi, nomad groups of population with unknown origin, organized themselves into smaller communities on the level of lineages with cattle raising as basic activity. 
on one or both sides. Originally, the roof is gabled with window. Roof cover is from shingle but mostly covered with unprotected iron tin which is regularly oxidized.

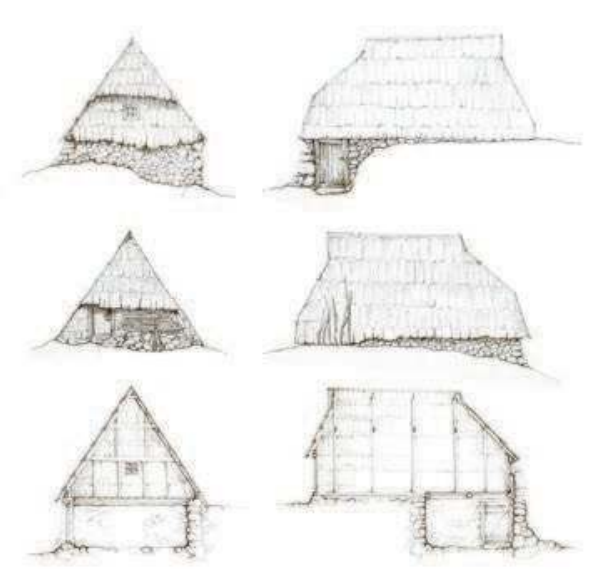

Fig. 9. Drawing of "katun" 50

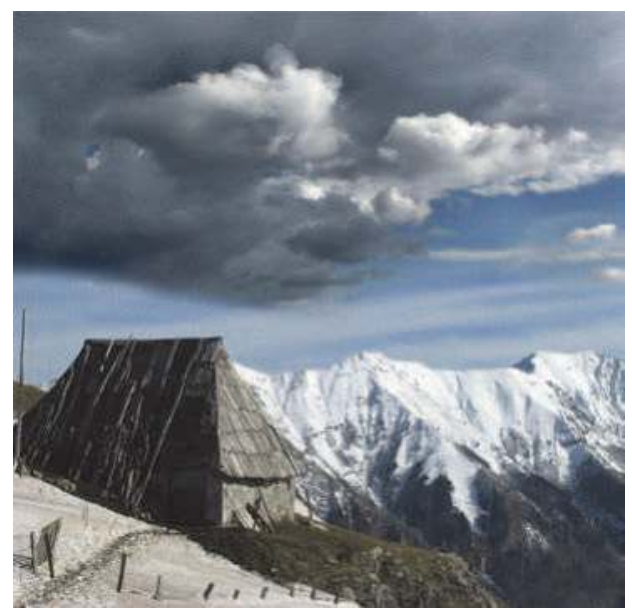

This description of facilities found in site partly differ from description by Muhamed Kadić who says that summer "katuns" or shepherds' cabins are one floored with open fine in the middle and straw on the roof. ${ }^{51}$ It may be supposed that these forms have evaluated and within traditional values, performed transformation in the sense of enlargement of facility for entrance space, understandably, because of climate conditions. We remind to the part in which, within the charter on vernacular heritage, it was stated:" Vernacular building is natural and traditional manner in which the communities make houses by themselves. It is long lasting process including necessary changes and permanent adjustment as the answer to social and ecological limitations..."52

All stone constructions of walls and supporting walls are $50 \mathrm{~cm}$ of thickness with minimal quantity of mortar or in form of dray wall while the wall mass provides static stability of facility. Details of wooden elements on the facility are processed roughly, with no protection, while the impregnation of wood happened because of soot from inside part.

Village Gradina is one absolutely authentic preserved space on mountain Bjelašnica and it should be preserved in original condition by the procedure of conservation and restoration insisting on traditional and original elements and of authentic manner of material processing.

\subsubsection{Type of stone floor house}

This type was not described by the book of Dr. Kadić probably because he didn't consider it as autochthonous type of Bosnian traditional, village house. Still, from the time distance of

\footnotetext{
50 Chabbouh-Akšamija, L. (2009). The Authenticity of the Rural Architecture as a Prerequisite for Active Protection; The Pilot Project Bjelašnica Village Ledići, Sarajevo.

${ }^{51}$ Kadić, M. (1967). Old-fashioned village house in Bosnia and Herzegovina, Veselin Masleša, Sarajevo.

52 ICOMOS Meksiko, oktobara 1999.Charter of the Built Vernacular Heritage, 1999.; Poglavlje: Smjernice $\mathrm{u}$ praksi, 3. Tradicionalni sistem građenja;
} 
almost hundred years, and with conscious about the idea of their builders for creating own picture of the ambience in which to live, it is considered that this type of the house deserves full attention as the previous one. Village Ledići is the only one with preserved remaining of such facilities while the village Prečani, where this type also appears, is today completely destroyed. Characteristics of these houses are that the facility was exclusively from stone, with smoothly hewn house corners and roughly hewn stone often poured with mortar and built in sheeting. Facility was build over the storage not exclusively placed vertical on the ground, thus, the storage was somewhere longitudinally placed in relation to facility. Ground floor/floor was with two entrances aside the house while the floor was often lower and with pediment walls bearing roof construction. Much steeper roof with struts often gabled with window in details differed stone floor house from its autochthonous for of Montenegrin house.
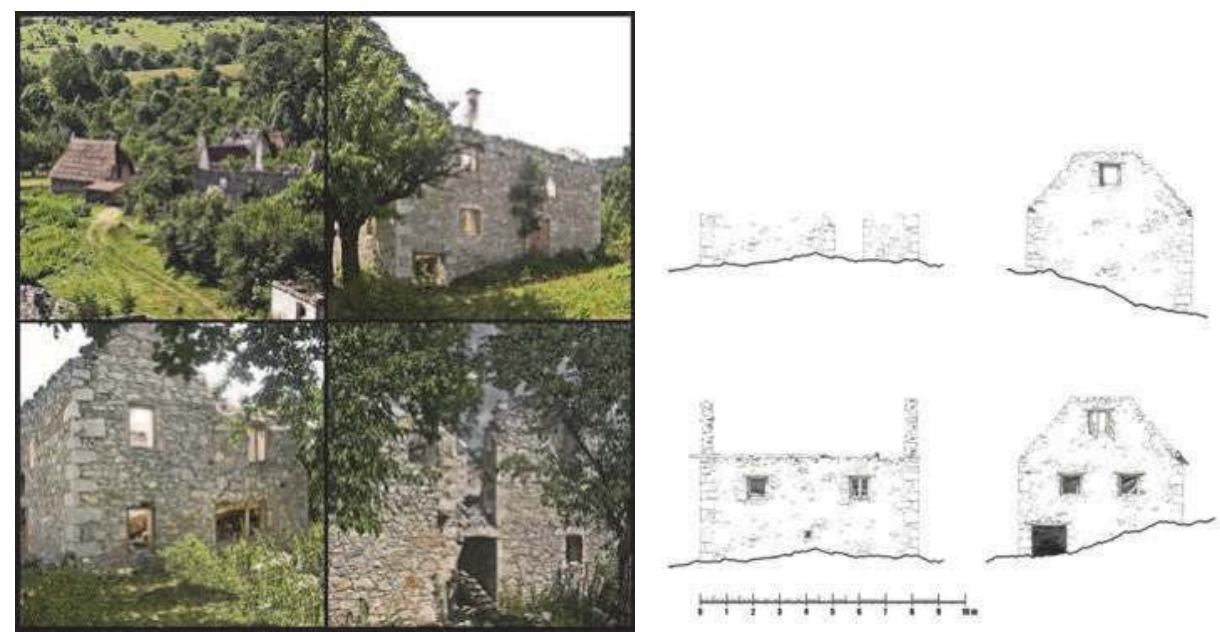

Fig. 10. Type of stone floor house 53

The following difference is in the shaping and construction of openings where the Montenegro stone house has smoothly processed stone beams in the function of over window and pediment beams or whole stone window frame, while on Bjelašnica the wooden beams were used for this function in the same way as at stone house with "čardak". This element is traditionally characteristic of the Ottoman period, and as these facilities were built between 1918 and 1920, it is logical to conclude that there has been a sublimation of all previous construction experiences and local traditional knowledge including brought knowledge and experience of these peoples' builders.

\subsubsection{Type of "čardak between roof beams"}

If it could be said that within local division a type that is the most characteristic for all territory of Bosnia may be detected, then it is a type of "čardak" between roof beams. Specific features of this construction in relation to other semi-floor facilities of Dinaric type

${ }^{53}$ Chabbouh-Akšamija, L. (2009). The Authenticity of the Rural Architecture as a Prerequisite for Active Protection; The Pilot Project Bjelašnica Village Ledići, Sarajevo. 
and Alps cottage, are that the front wall in the ground floor is extended by the "čardak" wall on the floor, and hipped roof from all sides framed this vertical surface, cutting it in horizontal, like coming out from it. In this manner, thermal protection of "čardak" is provided and visual experience is much better. Parallel, the opening of vertical windows on "čardak" was possible at which the composition looked compact. It is about rectangular floor plan, vertically placed on terrain thus the front side is the narrower side of the house and the storage space had openings both from the front and side part of the house. By vertical, the house had storage, ground floor/floor part, depending on what side the facility is perceived, and "čardak" in the function of a floor hidden within roof beams. When talking about similar forms and types of "čardak" between roof beams or about sub-types, it may be stated that besides cottage there are more types of "čardak" in the form of stone house which maintained disposition of cottage and "čardak" with the walls from wood and stone in combination.

- Type with wooden construction of "house" over storage / cottage/

This type of facility completely disappeared from the spaces of the Bjelašnica Mountain. On their previous locations, from not so far, new facilities appeared which are in disharmony with ambience. Village Rakitnica had the most representative examples of this house but today no one has been preserved. Detailed description of this type of house may be found at Dr. Kadić54

- Type of stone house with "čardak" between roof beams

This type of "čardak" between roof beams developed on East downhill of Bjelašnica, towards Treskavica getting later its final form. It is often about the roof which is hipped, the front wall with "čardak" has the form of pediment while the fourth roof plane appears in the form of window ("lastavica"). Disposition of the facility remained the same.
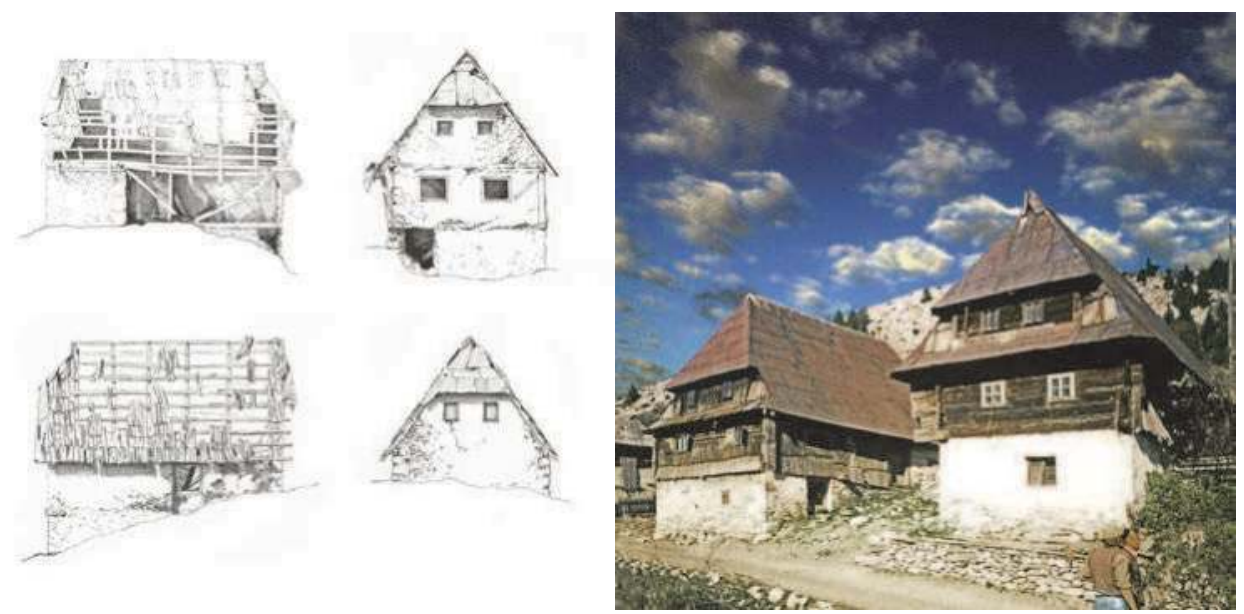

Fig. 11. Type of "čardak between roof beams" 55

\footnotetext{
${ }^{54}$ Kadić, M. (1967). Old-fashioned village house in Bosnia and Herzegovina, pp. (50-56), Veselin Masleša, Sarajevo.

${ }^{55}$ Chabbouh-Akšamija, L. (2009). The Authenticity of the Rural Architecture as a Prerequisite for Active Protection; The Pilot Project Bjelašnica Village Ledići, Sarajevo.
} 
- Type of "čardak" between roof beams from "dizma" and stone

This type of house, found only in village Ledići, has the front wall from "dizma" and the side walls placed on the ground made from stone. Disposition remains the same both in vertical and horizontal lines.

\subsection{Directions for the action within defined zones}

On the basis of previous researches on the practical example of the Bjelašnica village Ledići, it may be concluded that the use of numerous analysis from different points of view is of extreme importance so as the use of all available instruments. Analysis of all data or information is examined from triple attitudes:

- in relation to surrounding

- in relation to unity

- in relation to detail

In the process of research it is necessary to perform more analysis such as:

- $\quad$ analysis of original conditions

- historic research

- $\quad$ artistic aspect of the value of the facility and unity

- $\quad$ static-constructive research

- $\quad$ analysis of existing conditions

- $\quad$ study of vanished parts

- comparison to contemporary ambience or similar historic constructions.

Adjusted methodology De Angelis is the starting point for specific operation in traditional village surroundings.

Characteristic ambience of the Bjelašnica village has its specific features which will be defined by directives and which protection and restoration will come out from action. Method of selection in the case of protection and restoration of village architecture is restoration. Leading by definition of term of restoration, by Athens Charter from 1931, was précised that in the place restoration stops, the reconstruction begins. Paraphrased, where materialization stops, hypothesis begins. Special attention while working on individual facility should be devoted to the reasons of degradation in order to take correct attitude at restoration-conservatory recovery. Consolidation as unavoidable method in this process understands works on fundamental parts of facility. Such approach provides consistent application of all structural and essential operation on the facility. Regularly, roof construction is worked out by reconstruction method which, if we are not in the position, has not to be a facsimile, but it is reached through comparative approach. It should be insisted, in the process of preservation of authenticity, that authentic materials are used installed in traditional manner. Contrary, all restoration operations are pure copying and do not differ much from reconstruction. In the case of dilemma, whether new construction or reconstruction, it is, wherever possible, in favor of reconstruction. This is, of course, question of the individual attitude but the argumentation for such an attitude, with intention to be a recommendation, is that on so small territory it is very dangerous to have big creative freedom because the perception of space is such that, the slightest mistake may be fatal for overall ambience.

Still, as reconstruction often may be transformed in replica thus degrading ambience, the best solution is new construction with reminiscence to traditional values. This is the only space which, as the solution, may not accept the method of contrasts. Full analysis should precede construction of new facility which will establish limits of possible creation in the 
sense of measure, proportion of elements, selected form (mutual and internal) and, of course, materialization. While determining value of the whole ambience entirety it should act according to same principles as when talking about individual facility. It may be concluded that no new construction, no matter how acceptable (especially when talking about overall ambience entirety) it is, may be competition to authentic locations. Reality of determining authenticity, when ambience unities are under question, is accepted through the fact that there is dominant ambience benchmark that must be treated as referent values. Contributing is the fact about traditional form and function in certain ambience. If the possibility of function change is accepted, then such change may not go into direction of degrading existing condition or the original one. It has to be stopped on the level of compatible functions which do not disturb ambience value of space. More precisely, ambience is, in this case, top reference; it is defined by all individual elements and their mutual relations. Each violation of any of quoted relations brings to devastation and degradation. Important element in the process of analysis and research is valorization, as conclusive reference of space which is being given on the basis of performed analyticresearch process. As it is about the unity, real valorization may be done only within the overall treatment of the whole ambience. Each of the facilities which would violate ambience of space should be re-designed or removed. As in village unities, the case is not about high value facilities, valorization may be done in few steps.

- the first criterion would be classification according materials, measure and proportion

- the second criterion would be classification according time of construction

- the third criterion would be classification according to conditions of preservation.

It should not forget that in this case they are not only facilities that make an ambience. Important role is played by natural surrounding. Every devastation of natural values influences directly the value of selected ambience unity.

Recommendation from this work is that by announcing some zone as protected the wider zone also should be protected. Thus, it is recommendable to plan the zones of integral, active protection which would, by specific rules, protect whole complexes with more ambience valuable and familial unities. Method of network functioning and sustainability is based on integral offer of more smaller unities which by their disposition of activities supply central point to which all other unity in integrally protect space gravitate. Legislation has the foundation in international conventions but the biggest role has local community which, in correct manner and duly, may act in this direction. All dangers from illegal construction and incorrect use of space by such care, inspection supervision and well founded legislation, may be forestalled and prevented.

\subsection{Strategic goals for protection of integral rural heritage 2.15.1 Physical inseparability of integral rural heritage}

Physical inseparability of integral rural heritage understands the following:

- Legislation, legal and normative framework of actions for the preservation of the physical integrity of accented zones of active protection of integral values of space (regional, national and international level)

- Shaping and arrangement of physical integrity of historic urban landscape along with identification of directives that would be implemented through legislation

- Documentation related to physical integrity of accented zones of active protection of integral values of space 
- Application of all available technologies related to preservation of accented zones of active protection of integral values of space

- Education on all levels as prevention manner for preservation of these spaces

- Role of international governmental and non-governmental organizations in preservation and development of these spaces

- Development of awareness about traditional values of integral heritage over public media, participation to round tables, public gatherings,

- Presentation of non-material cultural values for the sake of their popularization and understanding of authentic rural architecture.

\subsubsection{Functional inseparability of integral rural heritage}

Functional inseparability of integral rural heritage understands:

- Legislation, legal framework of the actions for preservation of functional unity of historic rural landscape (regionally, national and international), implementation, inspection and sanction;

- Thematic approach to integral rural heritage

- Policies and strategies related to functional unity of rural historic landscape and modern infrastructural network that may jeopardize authenticity necessary for sustainable development

- Influence of tourism to physical and functional integrity of these unities

- Documentation of historic rural landscapes in order to maintain functional unities

- Influence of educational programs in the sense of maintaining functional unities of these ensembles

- Consciousness in media and public, the role of selected representatives, participation of local communities and population in preservation of functional unity of landscape

- Non material values and identity: Changing of manner of life and revision of previously undertaken changes that disturbed authenticity in order to maintain functional unity of space.

\subsubsection{Visual inseparability of integral rural heritage}

Visual inseparability of integral rural heritage understands:

- * Legislation, legal framework of the actions for preservation of functional unity of historic rural landscape (regionally, national and international), implementation, inspection and sanction

- Policies and strategies for preservation of authentic visual unity of integral heritage according to all previous parameters: height, volume, horizontal line, roofs, their materialization, façade and its materialization, proportions in relation to the unity of ambience and in detail, measure, volume...,

- Documentation of integral heritage for preservation of its visual integrity

- The role of education on all levels for the sake of visual integrity of these rural unities

- Role of governmental and non-governmental organizations in preservation and development of visual integrity of traditional rural landscapes,

- Development of consciousness on visual integrity of historic rural landscapes through media and public addresses

- Visual integrity and its influence to collective memory and cultural identity of community 
- Visual integrity and values of non-material cultural heritage

- Visual integrity and feelings for the spirit of space (genius loci)

Through this strategic approach it was tried to gather all relevant factors which directly influence the process of authenticity preservation. The whole process, naturally, follows after the first phase related to determination of authenticity, and other phases of protection of authentic integral heritage. Process of preservation and use of the accented zones of rural heritage represents special project with equal participation of legislation, education, economy, tourism as its branch, civil society and overall population not only from the space of action but also those who indirectly use it. Conscious about the importance of tradition and its real value is the most essential factor for successful realization of this project.

\subsection{Cultural tourism - concept of the use of rural integral heritage}

Analyzing tourism in rural architecture it was stated that the situation is more complex than anticipated, and that general picture is of double character. Namely, while perceiving complexity of the unity represented by integral rural heritage, a need for different treatment of certain elements finally connected to unity imposes. During the process of active use, the procedure of reconstruction and protection is different thus the process of designing concept of use, demands analytic approach to each element of this integrated space separately. Depending on the level of valorization evaluation of the space value, the concept of use starts from the attitude that the space is adjusted to purpose to the attitude that the purpose adjust to space. The approach when purpose adjusts to space is optimal form of the use of heritage and recommendations are directed in this regard. Still, often, (accepting all reality of situation, that on the ground we do not meet valorized zones of integral rural heritage), possibility that space adjusts to purpose is more probable. In the case when space should be adjusted to tourism purpose, care should be directed to minimal comfort and reorganization of interior adjusted to massive use. It is also necessary to reorganize existing structure of village because the contents of public character should be inserted into sensitive rural tissue. Elements of urban fittings and urbanized structure of village are contradictory notions with village ambience thus creating a problem. Limit to which commercialization and urbanization may go is very delicate. Small mistake may bring to incident in space. Sometimes these interventions act as the construction of "the ship in the bottle".

The second problem appears because of the relation between natural surrounding and the activities of infrastructural network to it. Traffic and traffic lines becoming unconditionally asphalt roads, parking places taking majority of resort, waste left with no care, water flows covered with garbage, meadows being destroyed by different sport activities and other harmful activities are only a part of human action to environment. Tourist trend of seventies and eighties of last century fighting for "wild" tourism, where tourist paid to stay in houses with no electricity, to sleep on straw bed, make fire with no matter to season in order to prepare food, is long behind us. Today, it is expected from tourism staff to organize comfort stay of guests who from all adventure called "return to nature" offer sojourn in villages where healthy and natural food is prepared and spaces for some of extreme sports.

Bjelašnica village Ledići, mountains Bjelašnica and Treskavica, as reservations of nature, offer more than that although the consciousness about them has not been raised to adequate level. Actual condition is such that on the ski locations we have grouped housing buildings with the apartments in individual private ownership with visible lack of hotel capacities. The facilities of apartment type were constructed elementally neglecting the existing regulation plan, and selected forms, materials and measure, above all, as already quoted, are 
absolutely wrong. Such type of devastation of space made the whole complex of the sport center non attractive and non productive. Namely, besides a permanent construction site and neglected surrounding that still may be arranged, the biggest problem is presented by constructed facilities making absolute contrast with the nature of location. Such situation does not contribute to tourist engagement of local authorities but gives a chance to development and directed shaping of traditional villages. These spaces deserve special attention and their traditional values direct program of utilization to cultural tourism. According to the Charter on International Cultural Tourism from 1999: "Cultural heritage including art-effects, cultural landscapes, historic locations and urban surroundings so as the past and actual traditions, reflect and express long process of cultural development. In each city, on many regions and almost in every village the examples of cultural heritage and cultural activities may be found which may become tourist attractiveness if in marketing sense are prepared for market". .56

Territories of attractiveness considered as potentials of tourist attractive and as a motive for cultural tourism development are:

- archeological areas,

- architecture (ruins, famous facilities, whole cities, settlements and traditional village heritage)

- $\quad$ music and dance

- drama, theatre and movies

- language and literature studies

- $\quad$ religious fiestas and pilgrimages

- $\quad$ overall (national and primitive) culture and sub-culture.

Such attractiveness gets special importance in the context of cultural tourism where the culture is used as a product, or, where culture is valorized in economic sense. Definition of cultural tourism should be considered from more aspects and scientific disciplines that observe the same appearance in different manners.

- From economic point of view, cultural tourism is the placement of culture to tourist market with cultural and artistic products having cultural and economic values.

- From organizational pint of view, it is inter-sectoral connection of culture and tourism two complementary branches that should create a partnership relation and unite in shaping the common product. Cultural economy is developed this way (cultural industry or industry of culture) which during last decades was one out of four sectors with the fastest growth in the world economy.

- From tourism point of view, cultural tourism is movement of tourist motivated by cultural reasons. According to definition, it is related to those places that are not developed in tourist sense, but have local cultural potentials. It is sufficient that tourist, motivated by desire to know them, spend one day there, to pay for his stay including cultural and artistic experience he had and - we get cultural tourism.

- From cultural point of view, it is promotion of revived cultural goods and landscapes of one city (region or state) which brings to tourist memorable experience and discussion about it upon returning to his resident place.

\footnotetext{
56 Adopted by ICOMOS at the 12th General Assembly (Mexico, October 1999). International Cultural Tourism Charter, Managing Tourism at Places of Heritage Significance (1999), Available from: $<$ www.international.icomos.org/rapport-mexico.htm.>
} 
- From educational point of view, it is tourist journey with desire to research, get know and learn something new about national and local cultural values of the surrounding being visited. More and more, seminars, workshops, schools, courses and other educational contents are organized.

- From the marketing and public relations point of view, cultural tourism is management of reputation of one place, region or state based upon cultural goods and landscapes.

In other words, if all local potentials activate for tourists, so as for local population - we have cultural tourism. ${ }^{57}$ Perceiving all quoted characteristics, the question of feasibility of the adjustment of space to purpose finds its answer in the Charter on cultural tourism:

"Planning activities for implementation of tourism should assure adequate facilities for comfort, security and welfare of visitors which intensify the joy in visit but not unfavorably important influence to the look and ecologic characteristics of space" ${ }^{\prime \prime 8}$ It may be concluded that development of cultural tourism will be determined by a need for change, a need for affirmation and self approval, a need for rest and recreation, a need for company, need for knowledge and cognitions, need for seminal game, need for security, individualization of services, getting service from the first hand, outlet to "wild" regions, increased desire to learn on the spot, increased desire to live spiritually and physically on healthy way, travels motivated by cultural reasons, decision to travel in last moment, traveling of older people and the young will be increased, maximal experience in minimal time period, quality traveling under favorable prices, value for money, differentiation of tourist product by quality, search for unusual, getting prestige, ...Many trends of tourist industry of XXI century according to predictions of experts, futurologists are: globalization, technological acceleration, changed behavior, stimulation of growth, syndrome of the home closeness, focus to itself, research, bigger intentions to learn manifesting in trials to know foreign cultures, bigger ecologic conscious, increasing desire to connect with nature, for getting experience from the first hand, more refinement in offer, more sensibility to quality, desire to protect the past and to accept the new...

It is clear that such support to correct articulation of tourist activity, could provide ecologic, economic and socially sustainable concept of the use of traditional rural unities.

\subsection{Results}

Results of research affirmed that from analyzed spaces a group of facilities disappeared which was called vernacular architecture and which was a reflection of traditional values of local peoples' builders that we consider as bearers of the basic message about identity of spaces and historical stratification. We confirmed that this stratified heritage has been produced in continuity over 2000 years and that its disappearance started in eighties of the past century. This time of the end beginning may be connected with the first signs of the global changes in social sense, thus, including the changes in other segments in space. Disappearance of this architecture from rural ambience, which existence is witnessed by rare remaining, brought towards the disappearance of the traces of the one group of people and their tradition. While analyzing traditional spaces, form of the space, materials from which the facility was built and ambience that was created by mutual relation of facilities, were taken into consideration. Concept of modern use of traditional facilities is given through the review of the characteristics of rural and urban heritage, and values that additionally

\footnotetext{
${ }^{57}$ Đukić-Dojčinović, V. (2005). Cultural Tourism, pp. (15-16), Belgrade.

${ }^{58}$ International Cultural Tourism Charter...- Principles, Article 3 and 4
} 
influence to one and other group of facilities were defined. Out from all layers of research according to original methodology, from details, individual facility, the urban matrix was only preserved partly as a result of ownership relations while re-selling or inheriting. It could be significant contribution in preservation of ambience structure but without individual values and traditional materials and forms, rural architectural heritage looses the battle with globalization. Through the strategy of preserving traditional values, we stated and practically approved that the solution is in contemporary architecture with reminiscence to traditional values. In this regard, we offer a methodology for the elaboration of the framework program which gives possibilities for researched and valorized values to become again the basis for contemporary construction.

\section{Conclusion}

Defining traditional values, their affirmation through modern trends of life and determination of solid frameworks of actions in shaping and conceptualization of new facilities, may contribute for modern construction with reminiscence to traditional values to be the form for expressing all modern needs through forms and materialization relied to traditional values thus coming to the balance between traditional architecture and modern trends. In that way, sustainability of such type of architecture will be provided with significant role of ecologic approach. Trial of uniting all positive aspects of traditional and modern through expression of needs from one side and searching for and bringing answers to needs from another side, would result in decrease of tension and ethic dilemma produced by the pressure that globalization creates. In our example it witnesses on complete disappearance of village architecture on the Bjelašnica Mountain.

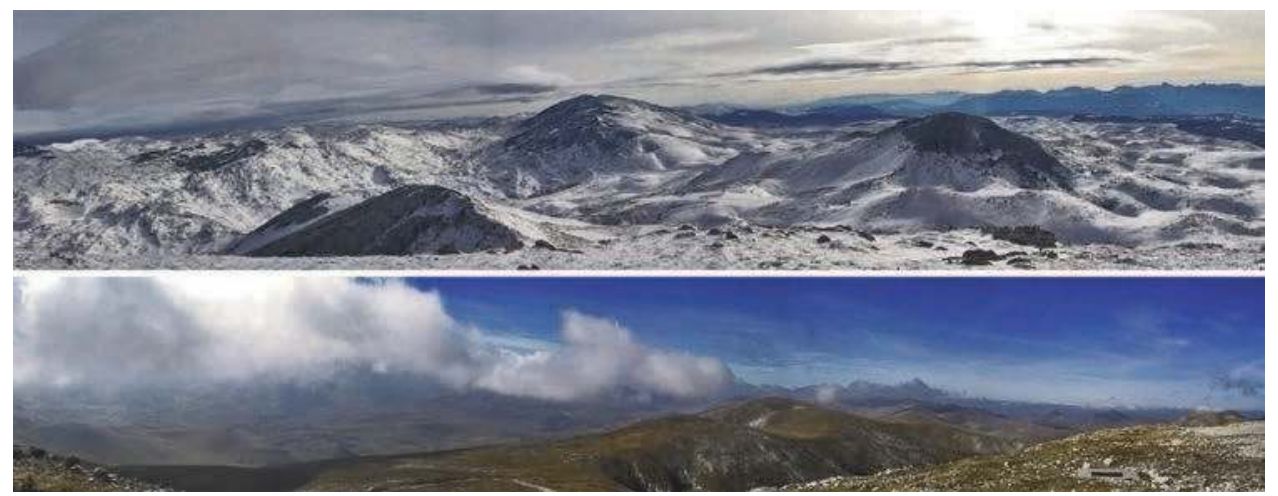

Fig. 12. Panoramic view of mountain Bjelašnica 59

Such attitude would in the same time help to transform global changes related towards construction into positive factor in creating space convenient for life. Trial to oppose to globalization, from the aspect of small and poor country with no attitude on national

5959 Chabbouh-Akšamija, L. (2009). The Authenticity of the Rural Architecture as a Prerequisite for Active Protection; The Pilot Project Bjelašnica Village Ledići, Sarajevo.

${ }_{59}$ Kadić, M. (1967). Old-fashioned village house in Bosnia and Herzegovina, pp. (50-56), Veselin Masleša, Sarajevo. 
identity in positive sense, looks merely Quixote. Possible solution lies in liberating from prejudices before essential and not semantic meaning of the word globalization. Following proposed methodology, accepting all knowledge gained through research, comparing and finally bringing conclusion, and respecting vernacular, new values in architectural shaping may be created not disturbing identity and integrity of traditional spaces. By researching continuity of construction on certain space on all four levels:

a. continuity in creating urban matrix,

b. continuity in individual physical structuring of facility (evaluated in relation to measure, volume, proportion, materialization and details)

c. continuity in functional sense

d. continuity in the sense of spirituality and idea of location (genius loci)

while designing with reminiscence to traditional values, at all quoted levels, the architect may refer to some of the segments.

\section{References}

Bobić, M. (1994). Ecotechnologic aspects of architecture, pp. (79-89), De re Aedificatoria Architecture and Technology, Belgrade (1987). Gesammelte Schriften, Bd. 7, Betrachtungen/Briefe/Rundbriefe/Tagebuchblätter, pp. (454), Suhrkamp Verlag, Frankfurt am Main

Chabbouh-Akšamija, L. (2009). The Authenticity of the Rural Architecture as a Prerequisite for Active Protection; The Pilot Project Bjelašnica Village Ledići, pp. (157), Sarajevo Collins English Dictionary - Complete and Unabridged $6^{\text {th }}$ Edition 2003; William Collins \& Co. Ltd, 1979, 1986 Harper Collins Publishers 1991, 1994, 1998, 2000, 2003

Čović, B. (1959). Trial Excavation on fort "Pod" near Bugojno, Archeological Review 1, Archeological Association of Yugoslavia, Belgrade, pp. (47-49)

Čović, B. (1961). Pod Bugojno - prehistoric fort, Archeological Review 3, Archeological Association of Yugoslavia, Belgrade, pp. (51-52)

Čović, B. (1963). Pod Bugojno - prehistoric fort, Archeological Review 5, Archeological Association Yugoslavia, Belgrade, pp. (30-33)

Čović, B. (1964). Pod Bugojno - prehistoric fort of early and late Bronze Age, Archeological review 6, Archeological Association of Yugoslavia, Belgrade, pp. (23-24)

Čović, Borivoj. (1965). Pod Bugojno - prehistoric fort of early and late Bronze Age, Archeological review 7, Archeological Association of Yugoslavia, Belgrade, pp. (5557)

Čović, B. (1966). Pod Bugojno - prehistoric fort of early and late Bronze Age, Archeological review 8, Archeological Association Yugoslavia, Belgrade, pp. (23-27)

Čović, B. (1967). Pod near Bugojno - fort from Bronze and Iron Age, Archeological Review9, Archeological Association of Yugoslavia, Belgrade, pp. (27-28)

Čović, B. (1968). Pod, Bugojno - prehistoric fort of Bronze and Iron Age, Archeological review 10, Archeological Association Yugoslavia, Belgrade, pp. (25-26)

Čović, B. (1968). Pod, Bugojno - prehistoric fort, Archeological review 14, Archeological Association of Yugoslavia, Belgrade, 1972, pp. (39-40)

Čović, B. (1968). Pod near Bugojno - prehistoric fort, Archeological review 16, Archeological Association Yugoslavia, Belgrade, 1974, pp. (54-55)

Čović, B. (1983). Central Bosnia Cultural Group, In: Bronze Age, Prehistory of Yugoslav countries $I V$, pp. (433-457), Sarajevo 
Čović, B. (1983). Central Bosnia cultural group, In: Bronze age, Prehistory of Yugoslav countries IV, pp. (433-457), Sarajevo

Čović, B. (1987). Central Bosnia Group, In: Iron Age, Prehistory of Yugoslav countries V, pp. (481-530), Sarajevo

Čović, B. (1991). Pod near Bugojno, Publisher National Museum of Bosnia and Herzegovina, Sarajevo Decision from the Commission to protect national monuments, Official Gazette BiH, No. 75, (2008)

Čović, B. (1983). Central Bosnia Cultural Group, pp. (433-434), Sarajevo

Čović, B. (1983). Central Bosnia Cultural Group, pp. (437-439), Sarajevo

Đukić-Dojčinović, V. (2005). Cultural Tourism, pp. (15-16), Belgrade

Hadrović, A. (2008). Bioclimatic Architecture on the Search of the Way to Paradise. Acta Arhitectonica et Urbanistica, Arhitektonski Fakultet u Sarajevu, Sarajevo, pp. (7-13)

Hawley, K. (2001). How thing persist, Oxford University Press, Oxford

Hegel, G.W.F. (1987). Phenomenology of Spirit, Introduction, pp.(17), Naprijed, Zagreb

Kadić, M. (1967). Old-fashioned village house in Bosnia and Herzegovina, pp. (50-56), Veselin Masleša, Sarajevo

Krainer, A. Equality in Variety - A Review of Bioclimatic Growth of Buildings on Yugoslav Territory, Proceedings in Variety of Fifth International PLEA Conference - PLEA'86, Pecs, 1986

Le Corbusier. (1998). Le Couvent Sainte Marie de La Tourette / The Monestery of Sainte... / Athen Charter, Paragraph 60, Arhitektonski fakultet, Belgrade

Lewis, D. (1986). On the plurality of worlds, Basil Blackwell, Oxford (2009). Random House Dictionary, Random House Inc.

McKinnon, N. (2002). The Endurance/Perdurance Distinction. The Australasian Journal of Philosophy, 80:3, pp. (288-306)

Merricks, T. (1999). Persistence, Parts and Presentism, Nous, No.33, pp. 421-438

Sider, T. Four-dimensionalism: An Ontology of Persistence in Time, Oxford University Press, Oxford

Quine,W.V.O. (1960). Word and Object, pp. (171), Mass: MIT Press, Cambridge

Zimmerman, D. Persistence and Presentism, Philosophical Papers, 25:22, Rhodes University, 1996, pp. (115-126). 


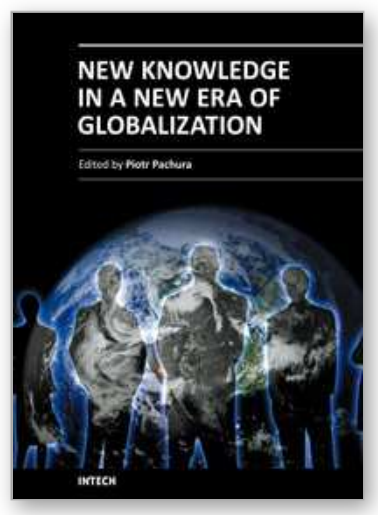

\author{
New Knowledge in a New Era of Globalization \\ Edited by Prof. Piotr Pachura
}

ISBN 978-953-307-501-3

Hard cover, 354 pages

Publisher InTech

Published online 01, August, 2011

Published in print edition August, 2011

To better understand the contemporary world, the world of innovation and technology, science should try to synthesize and assimilate social science in the development of our civilization. Does the new era require new knowledge? Does the age of globalization demand new education, new human attitudes? This books tries to clarify these questions. The book New Knowledge in a New Era of Globalization consists of 16 chapters divided into three sections: Globalization and Education; Globalization and Human Being; Globalization and Space. The Authors of respective chapters represent a great diversity of disciplines and methodological approaches as well as a variety of academic culture. This book is a valuable contribution and it will certainly be appreciated by a global community of scholars.

\title{
How to reference
}

In order to correctly reference this scholarly work, feel free to copy and paste the following:

Lemja Chabbouh Akšamija (2011). Future of Heritage - A Condition for Space Integrity, New Knowledge in a New Era of Globalization, Prof. Piotr Pachura (Ed.), ISBN: 978-953-307-501-3, InTech, Available from: http://www.intechopen.com/books/new-knowledge-in-a-new-era-of-globalization/future-of-heritage-a-conditionfor-space-integrity

\section{INTECH}

open science | open minds

\section{InTech Europe}

University Campus STeP Ri

Slavka Krautzeka 83/A

51000 Rijeka, Croatia

Phone: +385 (51) 770447

Fax: +385 (51) 686166

www.intechopen.com

\section{InTech China}

Unit 405, Office Block, Hotel Equatorial Shanghai

No.65, Yan An Road (West), Shanghai, 200040, China 中国上海市延安西路65号上海国际贵都大饭店办公楼 405 单元

Phone: +86-21-62489820

Fax: +86-21-62489821 
(C) 2011 The Author(s). Licensee IntechOpen. This chapter is distributed under the terms of the Creative Commons Attribution-NonCommercialShareAlike-3.0 License, which permits use, distribution and reproduction for non-commercial purposes, provided the original is properly cited and derivative works building on this content are distributed under the same license. 